\title{
El sepulcro turriforme conocido como la Torre de los Escipiones (Tárraco, Hispania citerior). Una nueva restitución con propuesta sobre su dedicante
}

\section{The Turriform tomb known as the Tower of the Scipios (Tarraco, Hispania Citerior): a new reconstruction and proposal as to its dedicatee}

Se presenta una nueva restitución fotogramétrica del sepulcro conocido como Torre de los Escipiones situado junto a la Vía Augusta, $6 \mathrm{~km}$ al noreste de Tárraco. La restitución ya publicada del carmen funerario sobre tabula ansata nos permite definir el sepulcro como un cenotafio y gracias a su aparato decorativo en piedra local resulta posible datarlo en torno al cambio de Era. No obstante, la decoración escogida para el frontal con dos imágenes de Atis resulta excepcional para esa cronología. El hallazgo en Mataró de una placa funeraria del primer duoviro quinquenal del municipio iluronense, L. Marcio Optato, miembro del orden ecuestre muerto en Frigia, nos proporciona una evidencia fundamental ya que Marcio es mencionado como edil en Tárraco antes de asumir el resto de su cursus honorum. Eso situaría en Tárraco a su familia, obligada igualmente a recordar su memoria con otro monumentum y explicaría de forma magnífica la decoración escogida de los Atis, la divinidad funeraria propia de Frigia y de toda el Asia Menor.

Palabras clave: Torre de los Escipiones, Atis, L. Marcio Optato, cenotafio.
This paper present a new photogrammetric reconstruction of the burial feature known as the Tower of the Scipios raised adjacent to the Via Augusta $6 \mathrm{~km}$ northeast of Tarraco. The previous published restitution of the funerary carmen on a tabula ansata identifies the tomb as a cenotaph. Moreover, its decorative elements made of local stone date the feature to the turn of the era. However, the two images of Atis decorating its frontal are exceptional in this timeframe. The discovery in Mataró of a funerary plaque of the first five-year duumviri of the Iluronense municipality of L. Marcio Optato, a member of the equestrian order who met his death in Phrygia, offers fundamental evidence as Marcio is cited as an aedile in Tarraco before assuming his remaining cursus honorum. The artefact would place his family in Tarraco where they were obliged to pay tribute to his memory by raising another monumentum. This also clearly explains the choice of the representation of Attis, the funerary deity of Phrygia and all of Asia Minor. 


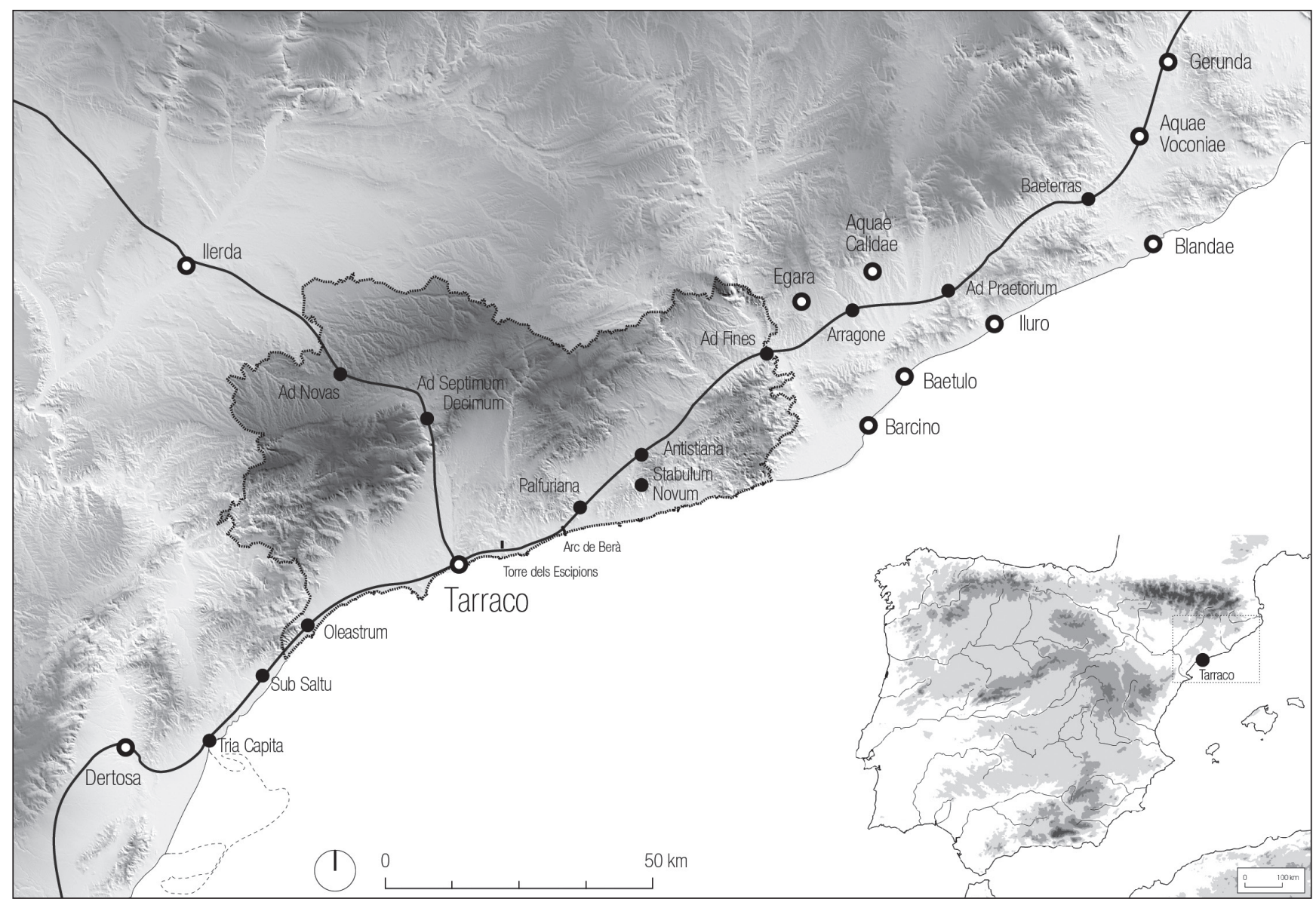

Figura 1. Extensión del territorio de la colonia tarraconense y trazado de las vías principales. Situación del sepulcro de la Torre de los Escipiones junto a la Vía Augusta, al NE de la ciudad.

Fuera de la ciudad (Atenas), en los demos y por los caminos, hay templos de dioses y tumbas de héroes y de hombres.

Pausanias, I, 29,2.

La llamada Torre de los Escipiones es un monumento funerario turriforme situado junto a la Vía Augusta, actual carretera N-340, muy cerca del mar, aproximadamente $6 \mathrm{~km}$ al noreste de la ciudad de Tarragona. Se trata de una construcción realizada en sillería, con planta cuadrangular $(4,47$ por $4,72 \mathrm{~m})$ y una altura conservada de c. $9 \mathrm{~m}$. Se levanta sobre una suave colina vecina a la costa y con vistas lejanas a la ciudad de Tarragona. La tumba consta de tres cuerpos superpuestos, separados por molduras y cornisas, acabados originalmente por una cubierta piramidal hoy perdida. En la fachada delantera aparecen dos personajes jóvenes vestidos con gorros frigios y ropas orientales, situados sobre pedestales. Sobre sus cabezas hay una larga tabula superior que contiene un carmen o poema fúnebre epigráfico, que hoy se conserva de manera incompleta. En el cuerpo superior, un nicho central contenía las imágenes en relieve plano de dos personajes en posición frontal y levantada. La Torre de los Escipiones es un monumento emblemático, declarada Monumento Histórico Artístico Nacional ya en 1926 (R.O. 28/07/1926, Ga- ceta 30/07/1926). Está catalogada como Bien Cultural de Interés Nacional de la Generalitat de Catalunya (BCIN 2025-MH-ZA), y forma parte de la lista de monumentos romanos de Tárraco reconocidos por la UNESCO como Patrimonio Mundial en el año 2000.

A pesar del nombre tradicional, es sabido que la tumba no guarda ninguna relación con los hermanos Cneo y Publio Cornelio Escipión, imperatores de las primeras legiones romanas llegadas al puerto de Kesse / Tarrákon los años 218 y 217 a. C., al iniciarse la Segunda Guerra Púnica. Ambos generales murieron combatiendo a los cartagineses en las batallas de Castulo e Ilorca, en la actual provincia de Jaén, durante el año 211 a. C. Tampoco existe ninguna relación con su hijo y sobrino Publio Cornelio Escipión el Joven, conquistador de Carthago Nova en el 209 a. C., ciudad donde celebró las honras fúnebres de su padre y su tío, y que fue, años después, llamado el Africano por su triunfo ante Aníbal en la batalla de Zama, que puso fin a la Segunda Guerra Púnica. Ni tampoco con Publio Cornelio Escipión Africano minor, destructor de Cartago en el 146 a. C., que invernó con su ejército en Tárraco antes de asediar y destruir Numancia en el año 133 a. C., regresando luego triunfante a Roma. Ninguno de los cuatro Escipiones fue enterrado en Tárraco ni en sus cercanías. 


\section{Apuntes historiográficos}

No sabemos bien cuando surgió esta confusión entre los eruditos o qué leyenda local decidió tal atribución. La historiografía de los estudios sobre la torre ha sido ya tratada de forma detallada en una exposición realizada en 1993 en el Museu Nacional Arqueològic de Tarragona (Massó et al. 1993) y en un trabajo monográfico de J. Rovira y A. Dasca (1993) que analizaba las múltiples actuaciones de todo tipo realizadas sobre el monumento en los siglos XIX y Xx recogidas en el archivo de la Reial Societat Arqueològica Tarraconense. La primera mención de la torre, ya con su nombre atribuido a los Escipiones, se remonta a 1525, en el manuscrito del viajero y diplomático Mariangelo Accursio, humanista y epigrafista que pasó por Tarragona en esa fecha recopilando schede de 31 inscripciones romanas (Dupré 1992). Se repite en 1572/1573 con la mención ya detallada que publicaría en Lleida el abogado y anticuario tarraconense Lluís Pons d'Icart, que dedicó a la torre un capítulo entero (el XLV) de su obra Libro de las grandezas. Pons llegó incluso a presentar un árbol genealógico de la familia de los Escipiones en un intento de identificar como tales a los ocupantes del sepulcro en base a los trabajos de otros eruditos anteriores a los que él había tenido acceso (Joan Annio, Pedro Beuter, Pedro Medina, Gerónimo de Urrea). De su texto conocemos igualmente la versión original catalana que ha sido editada por E. Duran (1984) y ambos acreditan la atribución popular de la torre a los Escipiones en pleno siglo XVI.
La primera anotación gráfica, apenas un pequeño croquis, fue obra del pintor flamenco Anton van den Wyngaerde, contemporáneo de Pons d'Icart (Tarrats 2004; Remolà 2007: 51-52, fig. 3). Siguieron varios dibujos de carácter menor, hasta llegar a los dos magníficos grabados románticos con vistas de la torre incluidos en el libro de viajes del conde Alexandre de Laborde editado en París en 1806 (Valls et al. 1974). En la misma obra, un tercer grabado puede considerarse el primer análisis arquitectónico y epigráfico de la torre imbuido del espíritu de la Enciclopedie: alzado de la fachada delantera incluyendo su sección con medidas, reproducción precisa en detalle del carmen epigráfico y hallazgo sin precisar de una incineración en urna de vidrio dentro de una caja de piedra con dos pequeños ungüentarios y una moneda tiberiana de la serie Divus Augustus Pater y CUTT dentro de laurea, todos ellos seguidos de un comentario explicativo con bibliografía (Valls y Massot 1974: 130, planchas XLIII, XLIV y XLV).

Entrado ya el siglo xx, la Comisión de Monumentos vació todo el interior de la torre como parte de unos trabajos de refuerzo y consolidación realizados con hormigón (Butlletí Arqueològic 1924: 272; cf. Rovira et al. 1993). Fueron trabajos previos a su declaración como Monumento Nacional en 1926, pero desgraciadamente sirvieron de poco o nada desde el punto de vista investigador. En el apartado de los estudios recientes hemos de citar en primer lugar el de C. Cid Priego (1947) que hizo el esfuerzo de ordenar toda la información disponible incluyendo

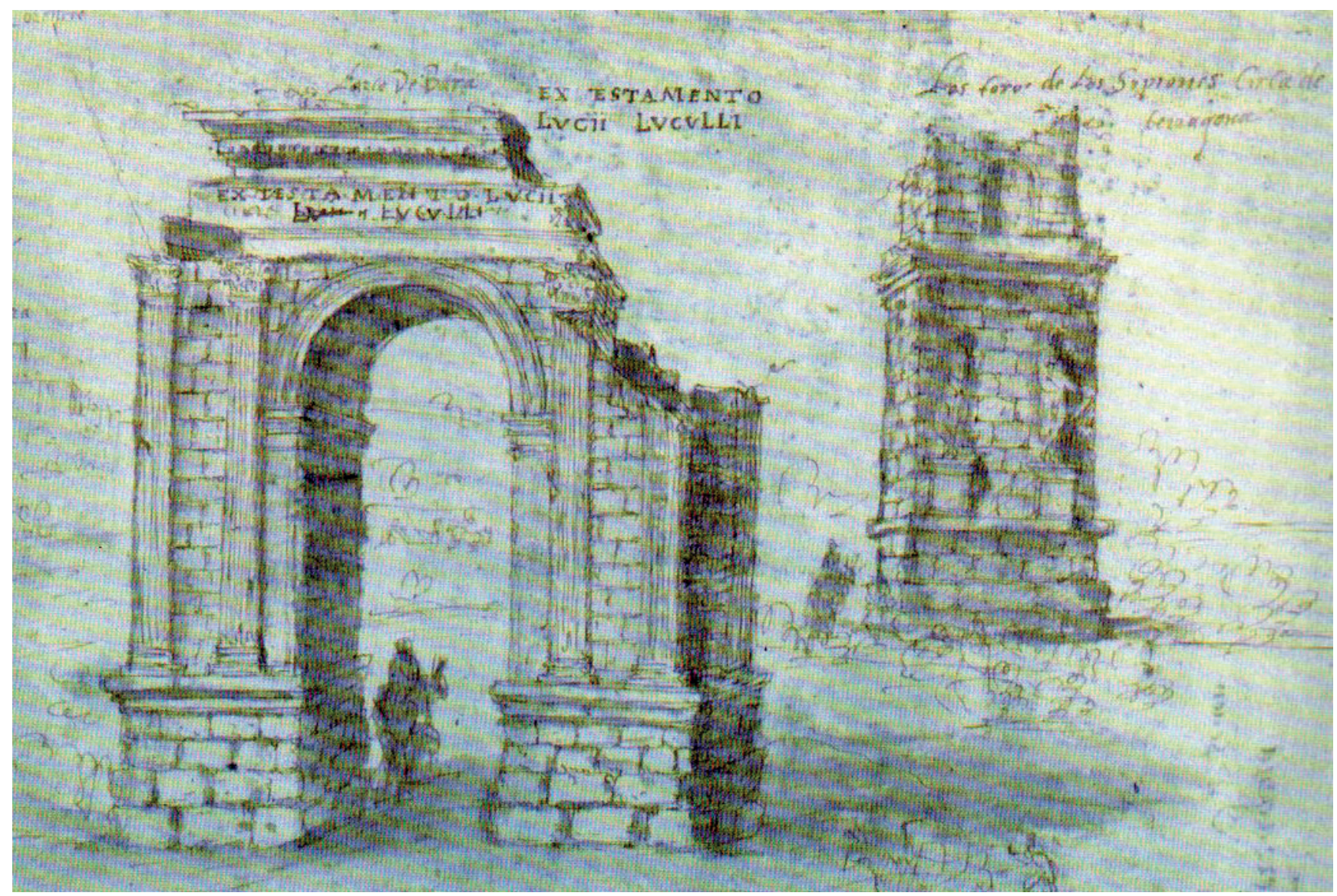

Figura 2. Dibujos de Anton van der Wyngaerde del Arco de Berá y la Torre de los Escipiones en 1572 (Ashmolean Museum, Oxford). 


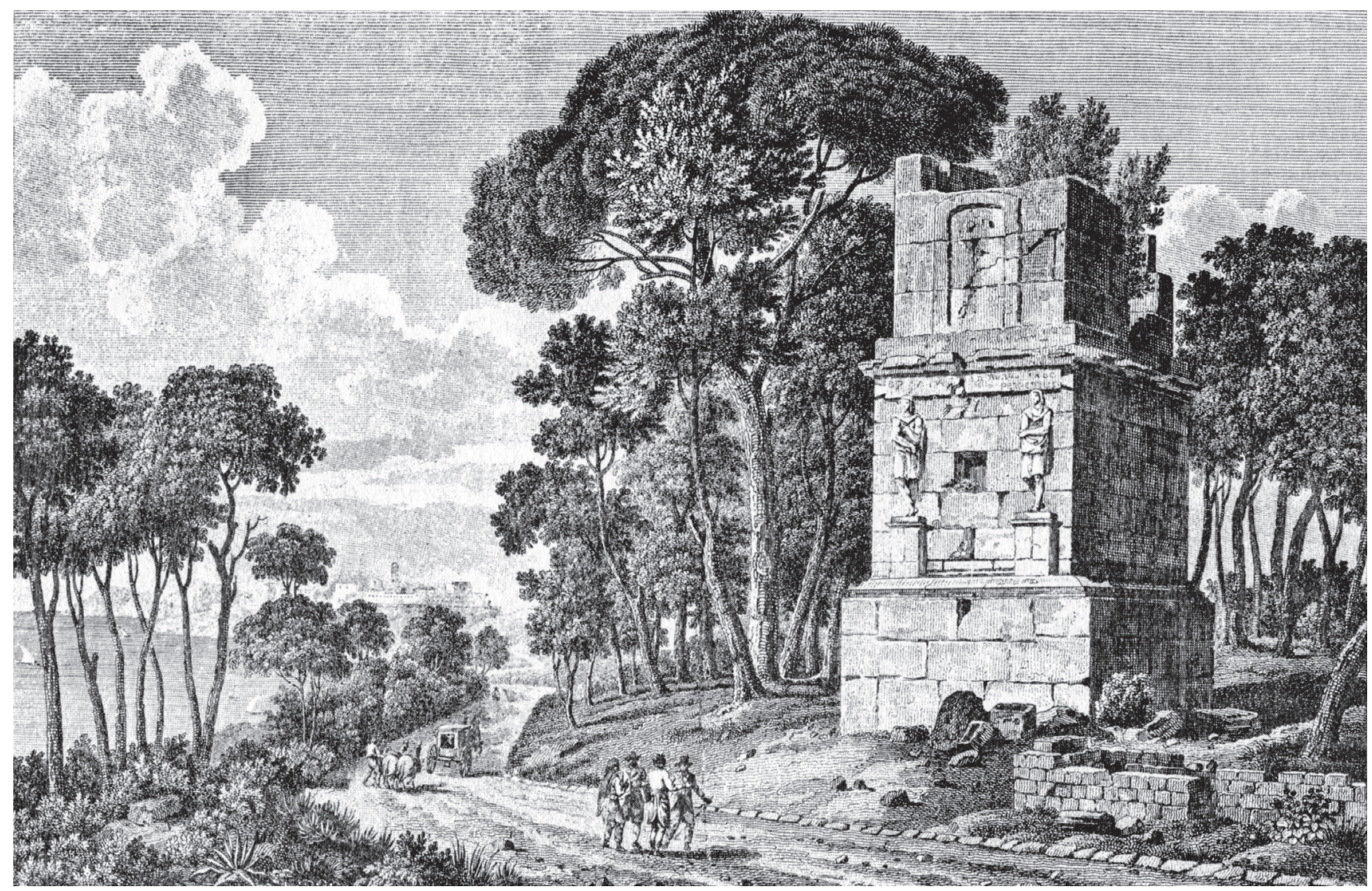

Figura 3. Grabado de la Torre de los Escipiones en el libro de viajes del conde Alexandre De Laborde a fines del siglo xVIII, con la posición del sepulcro junto al camino real y con la ciudad de Tarragona visible en el horizonte. Véase el detalle del agujero central entre las dos imágenes, de donde fue extraído en el siglo xvi un epígrafe de mármol.

las actuaciones sobre la carretera con la recogida de materiales arqueológicos e inscripciones aparecidas en torno al monumento que fueron depositadas en la cercana propiedad de Mas Rabassa. En los años siguientes, el trabajo fundamental fue realizado por Th. Hauschild, S. Mariner y H. Niemeyer (1966) que significó el primer estudio científico completo de la torre realizado desde todas sus vertientes: arqueológica, arquitectónica y epigráfica.

\section{El monumento y sus dos inscripciones: una anónima y otra desaparecida}

Para interpretar el sentido de la torre lógicamente hemos de intentar leer la inscripción que preside la fachada, desgraciadamente muy mal conservada. Se trata de una oración fúnebre en verso que se desarrolla en dos líneas superpuestas en el interior de una tabula ansata. El texto de este carmen epigráfico fue incorporado por E. Hübner en CIL II, 4283 incluyendo todas las referencias anteriores pero limitándose a transcribir las partes del texto aun legibles. El sentido global de la inscripción pudo ser restituido de forma sugerente por Sebastián Mariner en su trabajo conjunto con Hauschild y Niemeyer de 1966 gracias a la autopsia directa de la inscripción y a las fotografías muy precisas realizadas por el Instituto Arqueológico Alemán que acompañaron nuevos dibujos detallados del monumento. Más tarde, en 1978, su propuesta fue revisada de nuevo por Géza Alföldy (RIT 921) a la que nos referiremos más adelante. En 1993, Marc Mayer, Maite Miró y Ramon Perea volvieron a realizar la autopsia in situ de la inscripción, completando las partes perdidas con una propuesta global de lectura muy convincente. Años después, Joan Gómez Pallarès (2002, T-13, 111-116) abordó nuevamente la transcripción de este texto poético enigmático, por incompleto, con nuevas precisiones y una cuidada recopilación de las transcripciones anteriores.

Ante las lagunas del texto que no permiten nuevas precisiones de detalle, el sentido global del poema, con métrica de tres impares yámbicos (pie compuesto de dos sílabas, la primera breve y la segunda larga), sigue siendo el adelantado por Mayer, Miró y Perea.

Ornate ea quae linqu[it opera]se vi[tae] suae rebus posit [i]s negl[igen]s,

unum statuit e[nim sui]s (i) sep[ulc]hrum ubi perpetuo remane[ant],

"Enaltecer las obras que dejó al morir, olvidándose de él,

erigió para los suyos un solo sepulcro donde han de permanecer para siempre".

Una lectura algo diferente es la que propuso en 1975 Géza Alföldy en RIT 921, recientemente de nuevo revisada en su reedición de las inscripciones romanas tarraconenses bajo CIL II ${ }^{2}, 14,2306$. Se recogen y 


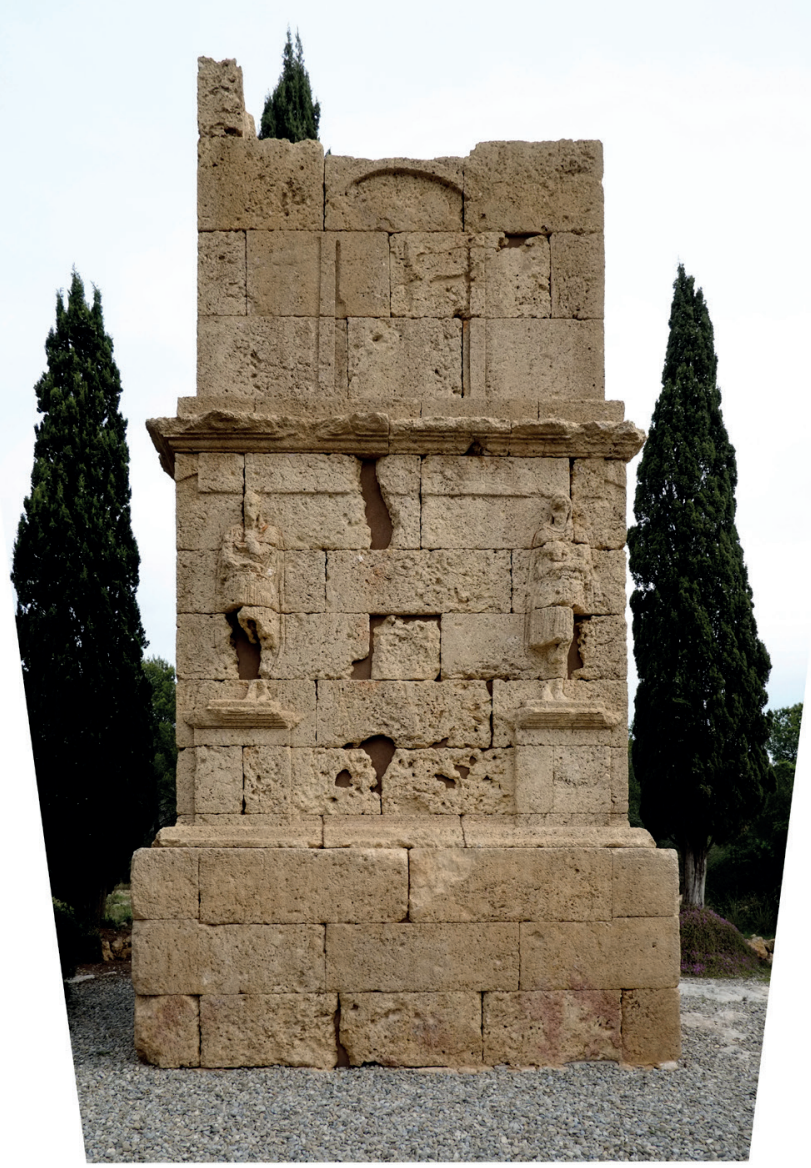

Figura 4. Vista frontal de la torre en la actualidad.

comentan aquí todas las referencias anteriores incluyendo la de Mayer, Miró y Perea, pero Alföldy se reafirmaba en su propia propuesta de lectura con un par de diferencias (que señalamos aquí en negrita) que dan ciertamente un sentido diferente al mensaje de la inscripción:

Ornate ea quae linqu[it specio]se vi[tae] suae rebus posit[i]s negl[egen]s,

unum: statui re[liqui]s (i) sep[ulc]hrum ubi perpetuo remane[nt],

"Enaltecer todo aquello que él dejó, después de haber vivido una vida espléndida, olvidándose tan solo de una cosa: haber dejado para sus restos un sepulcro donde permanezcan por siempre".

Ciertamente, esta poesía fúnebre nos indica con precisión un cenotafio: alguien que ya no está, y en cuyo nombre se dedicaría el sepulcro, ya fuera por una donación testamentaria propia o por la intervención de un pariente próximo. Ahora bien, para poder entender realmente este texto nos falta la que debía ser la pieza central y emblemática del monumento: un epígrafe sobre placa cuadrangular de mármol blanco, situada entre los dos Atis. Sobre este elemento capital, hoy desaparecido, en 1572 Pons d'Icart menciona lo siguiente:

Entre las estatuas o personajes (de la Torre de los Escipiones) avia una piedra de mármol alabastrino escripta, la qual piedra se llevó pasando por allí fray

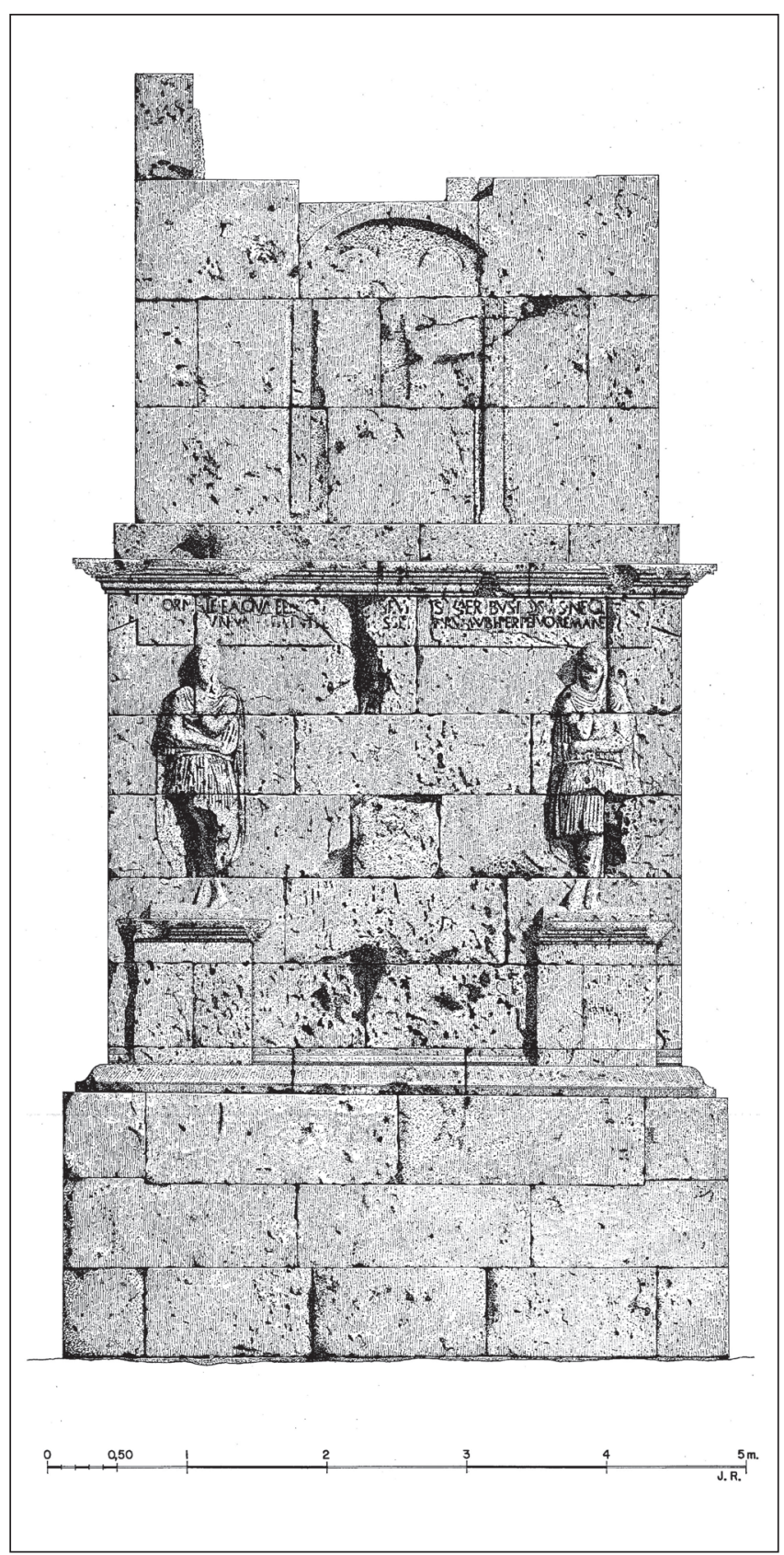

Figura 5. Alzado frontal de la Torre de Hauschild, Mariner y Niemeyer (1966).

Francisco Ximenez cardenal de España que fue curador grande tiempo de la reina Ysabel de gloriosa memoria y nunca se ha podido saber si la llevó a Roma o a Castilla. Yo por mi parte lo he procurado saber, por poder poner aqui una copia de la escriptura y no ha sido possible saberlo; Dios se lo perdone porque sin duda aquella escritura dava verdadera noticia de lo que aquella torre era, y el porque fue edificada (sic).

Y la cita es verídica. El grabado reproducido en el viaje de Laborde a finales del siglo XVIII muestra en el centro de la torre un claro rebaje cuadrangular en posición central, apropiado para un epígrafe central extraído. Aquí se ubicaría la imprescindible inscripción con el nombre de nuestro anónimo protagonista del poema superior o bien con el nombre de sus parientes y herederos. Durante los trabajos de desescombro de 1924 el sillar interior de este rebaje fue retirado para 
poder vaciar el interior de la torre con mayor comodidad y luego se volvió a colocar el sillar ajustado al muro exterior, una posición en la que aún permanece hoy disimulando la ausencia de la placa delantera.

Este epígrafe central debió llamar la atención —según la afirmación de Pons d'Icart- del poderosísimo cardenal Jiménez de Cisneros (1436-1517), confesor y consejero de la reina Isabel de Castilla, inquisidor general, regente y fundador de la Universidad de Alcalá. No se sabe nada más de este asunto. Como era de esperar, los biógrafos del cardenal Cisneros son reacios a atribuir esta pasión anticuarial a $\mathrm{Su}$ Eminencia, que además nunca estuvo en Tarragona, un capricho poco digno que empañaría su prestigio y sus virtudes. Pero Pons d'Icart lo afirma y la pieza falta.

Y no todo acaba aquí. El manuscrito del viajero y humanista Mariangelo Accursio conservado en la Biblioteca Ambrosiana de Milán que antes hemos mencionado como primer descriptor de la torre complica más la cuestión al afirmar, en 1525, lo siguiente:

Sepulcrum eodem lapidem quod scipionum vocatur et eorum fuisse creditur preacipue ex Inscriptione, quam Alexandri Pontifex amovit. Nam litterae suprascriptae, quae magna ex parte attritae sunt, vix arbitror etiam a prope contemplandi dignossi posse...

"[Hay] un sepulcro de la misma piedra [que la del Arco de Bará] que se llama «los Escipiones», y se cree que fue, sobre todo, por la inscripción que sustrajo el papa Alejandro [VI Borgia]. En efecto, las letras que están escritas encima, que en buena parte están desgastadas, pienso que con dificultad serán descifradas incluso contemplándolas de cerca" (Ms. Ambro. 0148 sup., cf. Dupré 1992: 48).

Este tipo de sustracciones de lápidas eran muy frecuentes en un siglo xvi cuyos eruditos eclesiásticos y civiles tenían en la epigrafía una nueva pasión de coleccionismo generadora por ejemplo de producciones falsarias que podían ser vendidas a muy buen precio (González y Carbonell 2002). No sabemos nada con certeza, pero el asunto de la lápida robada de la Torre de los Escipiones afecta a dos personajes de la fama del cardenal Cisneros y del papa Borgia.

\section{El aparato decorativo de la torre}

Como decíamos, la torre está formada por tres cuerpos, el superior de los cuales se conserva solo en parte. El primer cuerpo es un zócalo o pedestal de 1,8 m de altura. En la fachada orientada a la Vía Augusta, los dos laterales del cuerpo central están decorados con los altos relieves de dos estatuas encima de pedestales. Son dos jóvenes genios funerarios vestidos con ropas orientales: gorros frigios, bracae o pantalones abombados y capas. Los dos genios tienen las piernas y brazos cruzados y las manos derechas apoyadas en los mentones. Ambas estatuas mantienen el gesto pensativo, aspecto y vestuario característicos del joven pastor frigio Atis, compañero de la gran diosa Cibeles / Magna Mater en sus ritos anuales de muerte y resurrección. Volveremos más adelante sobre las mismas.

En el tercer cuerpo superior de la fachada delantera, hay un bajorrelieve de dos figuras humanas bajo un sencillo arco rebajado. Solo podemos apreciar el contorno de sus formas, y es probable que ambas estuvieran en realidad moldeadas directamente sobre la argamasa de recubrimiento. El arco se repite en las dos caras laterales, por lo que tenemos que imaginar que la decoración de la torre estaba preparada para acoger sucesivamente diferentes matrimonios descendientes de la familia. En la cara superior de la última hilada de sillares se observan todavía los encajes de las grapas. El monumento se debía completar con una cornisa superior y una cubierta, probablemente piramidal, terminada en una piña funeraria como coronamiento.

La torre está construida con sillares de piedra local de tipo sedimentario o lumaquela similar a la extraída en la vecina cantera del Médol. Es la piedra característica de todo este tramo de la costa tarraconense y probablemente fue extraída de cualquier afloramiento cercano. En la cara posterior del sepulcro se conserva puntualmente el enlucido de 1,5 cm de espesor que revestía los paramentos de sillares. También los Atis de la fachada delantera tenían los detalles labrados encima de una capa de estuco de revestimiento que aún conserva restos de la policromía en rojo. Los colores intensos fueron, pues, una de las características decorativas del monumento.

\section{Documentando de nuevo la Torre de los Escipiones}

Para llevar a cabo el proceso completo del estudio del monumento funerario hemos utilizado diversos programas de tratamiento de datos y modelado tridimensionales en entorno virtual (Gris y Ruiz de Arbulo 2015). Ferran Gris ha realizado el levantamiento fotogramétrico, con el objetivo de obtener un modelo tridimensional del monumento que nos aporte tanto el volumen, como el relieve y la textura de la superficie. Este levantamiento automatizado se vio facilitado porque la torre había sido recientemente objeto de una intervención de limpieza y consolidación.

Las 139 fotografías utilizadas para el levantamiento fotogramétrico, se realizaron a lo largo de una mañana aprovechando las condiciones lumínicas favorables de un día nublado. La lente utilizada es una óptica fija de $18 \mathrm{~mm}$ (equivalente a $27 \mathrm{~mm}$ en formato estándar de $35 \mathrm{~mm}$ ). La configuración de la exposición se mantuvo constante de manera que se conseguía una buena profundidad de campo a la vez que se evitaba la trepidación cuando se usaba una pértiga para tomar las fotografías más elevadas - apertura f/5.6, velocidad de obturación 1/500 y sensibilidad ISO 400_. De esta manera se mantiene la misma exposición absoluta por lo que mejoran tanto el proceso de cálculo de la nube de puntos como la cualidad de la textura resultante. En el proceso de documentación hemos considerado el alto grado de precisión que se obtiene actualmente con la fotogrametría, lo que nos ofrece un buen balance entre precisión y usabilidad. El modelo que finalmente se ha utilizado se ha reducido a 200.000 caras con una distancia entre vértices en torno a los $5 \mathrm{~cm}$.

Paralelamente, se ha modelado en tres dimensiones el edificio a partir de los planos de Hauschild, Mariner y Niemeyer (1966). Hemos aplicado como texturas 


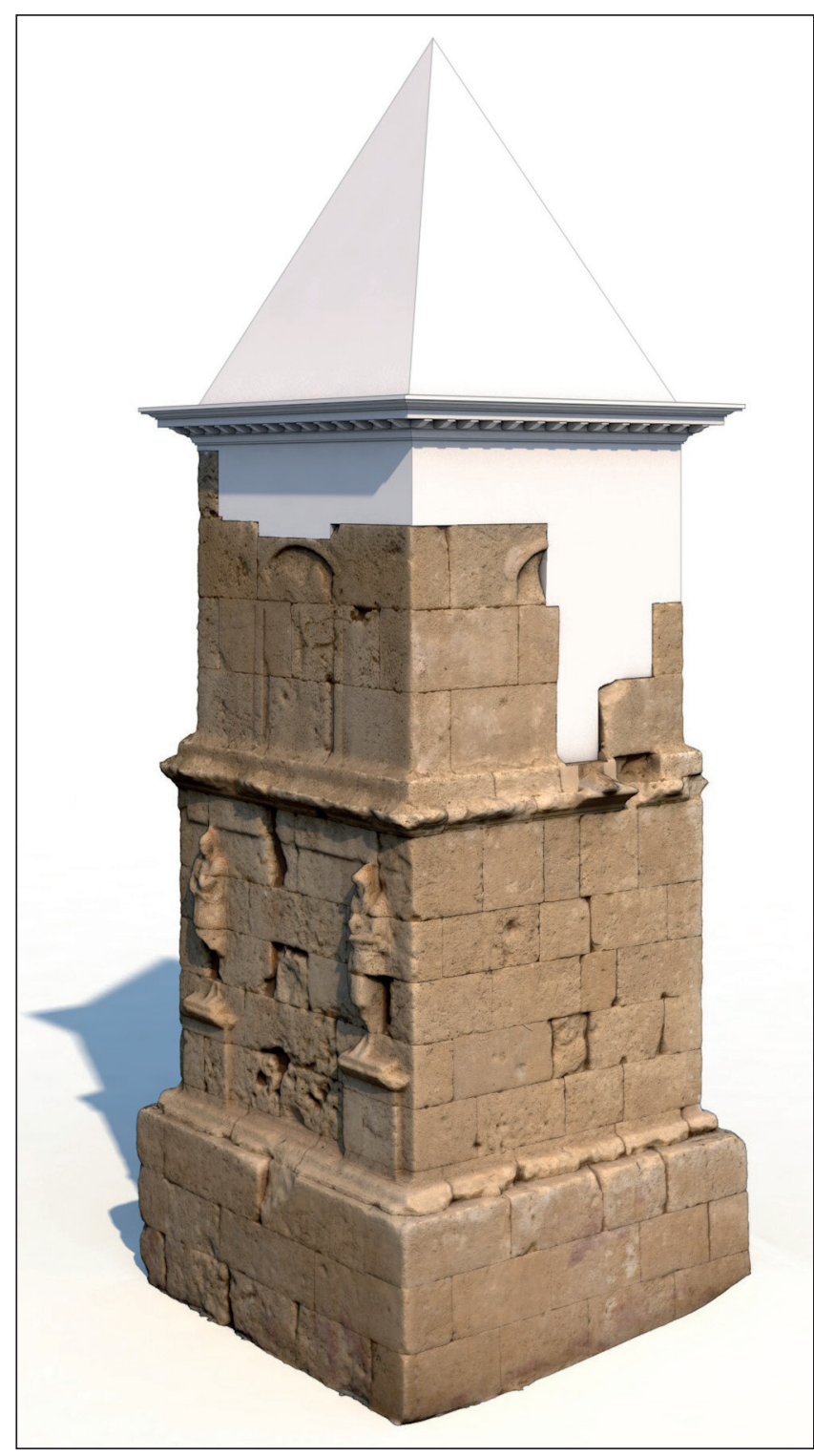

Figura 6. Ortofotogrametría de la torre con propuesta de restitución de la cubierta (Ferran Gris).

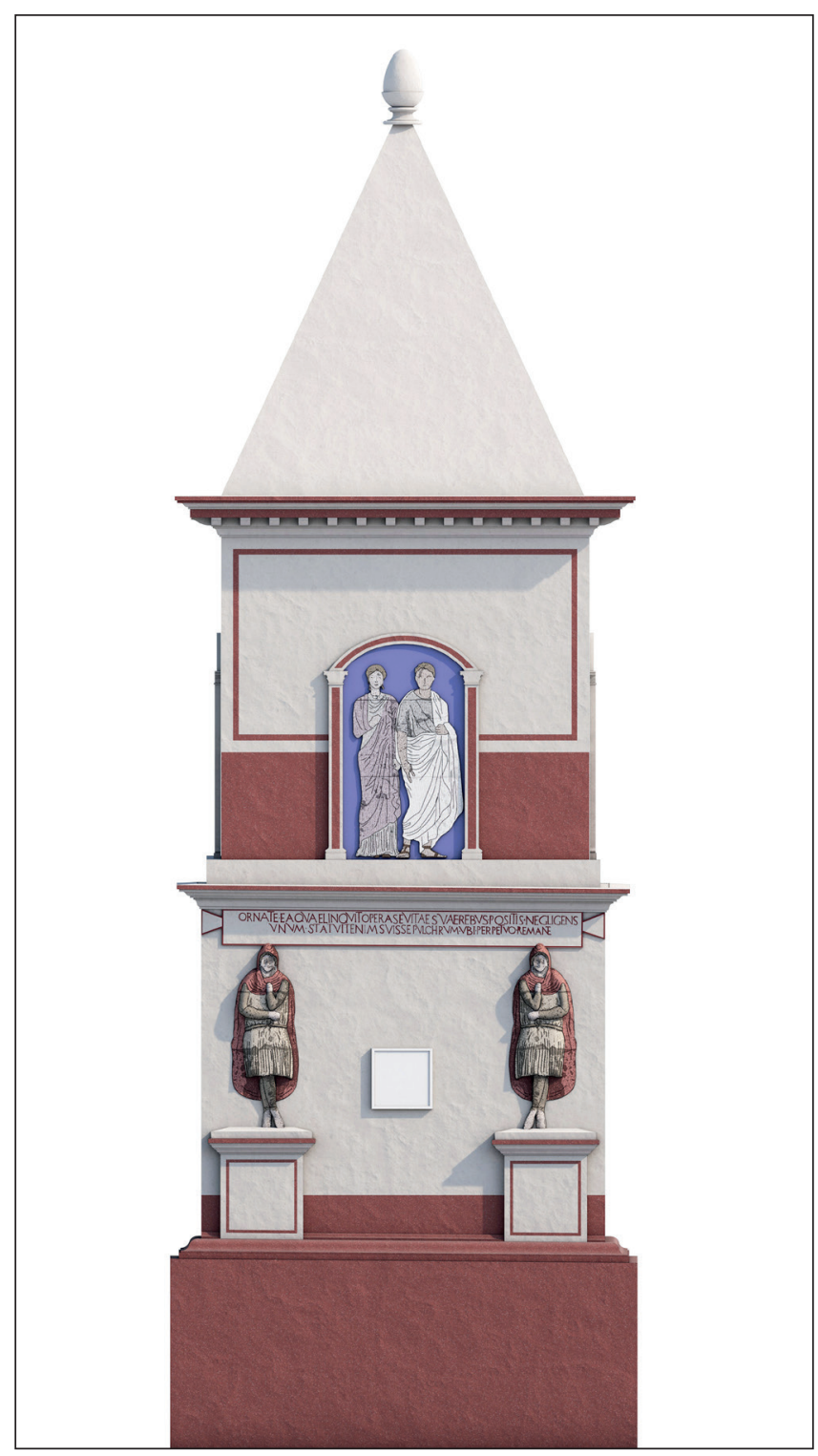

Figura 7. Propuesta de alzado frontal de la torre con restitución de la tabula epigráfica y la policromía original del monumento (Ferran Gris). los mismos planos, con el objetivo de mostrar visualmente cómo se ha construido este segundo modelo. La posibilidad de comparar en un mismo entorno virtual ambos levantamientos, el automatizado a través de la fotogrametría y el modelado manualmente, permite comprobar el gran trabajo de documentación gráfica realizada por el equipo alemán. Después de este trabajo de documentación gráfica y análisis de los restos hemos continuado con la restitución de las partes desaparecidas del monumento.

El problema focal de la interpretación es la solución arquitectónica que se aplique a la reconstrucción del cuerpo superior y la cubierta. Teniendo en cuenta que los orificios antes mencionados en los sillares superiores nos indican la existencia de una cornisa actualmente desaparecida, se ha valorado el papel formal y compositivo en sus detalles decorativos y en su función de remate del tercer cuerpo del monumento. Sobre el eje vertical, encontramos en bajorrelieve la falsa ventana o nicho con arco rebajado sobre pilastras que acoge la efigie también en bajorrelieve de dos personajes, interpretable como una pareja de difuntos.

Por otra parte, precisamos dar una solución arquitectónica a la cubierta misma. Para este tipo de monumentos contamos con un repertorio de tres soluciones diferentes - cubierta a dos aguas a modo de templo, cubierta a cuatro aguas y pináculo con forma de pirámide- Cada una de estas soluciones implica diferentes contextos constructivos y tradiciones arquitectónicas. En la elección de la tercera solución ha contado fundamentalmente la tradición decorativa local y sobre todo el tradicional trabajo de piedras locales revestidas de estuco pintado, que realizaron los talleres de cantería en los restantes edificios de Tárraco.

El pináculo por su parte estaría coronado por un elemento decorativo. Es la misma superposición de pirámide y capitel que Vitruvio (Iv, 8, 3) nos describe para los templos circulares perípteros y que tiene su 


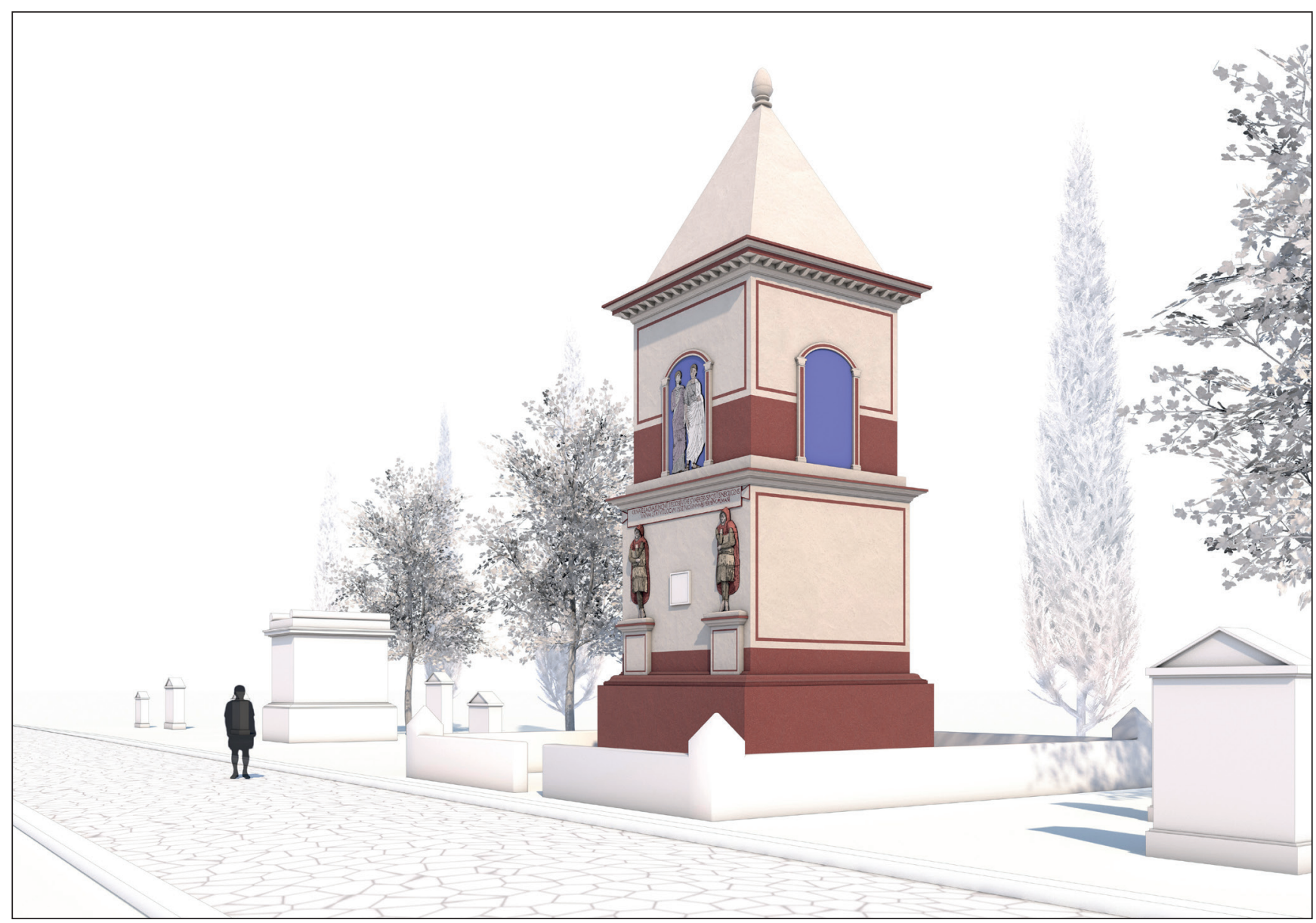

Figura 8. Vista lateral de la torre y del entorno de la misma como sucesivos recintos funerarios anexos a la Vía Augusta (Ferran Gris).

origen en la tradición helenística. En la tumba de Aefonius Rufus en la necrópolis de Sarsina, estudiada por S. Aurigemma, el pináculo protegido por esfinges en los cuatro ángulos culmina en lo alto en un capitel corintio y una bella urna funeraria ficticia. El motivo por el que inicialmente se situó una urna culminando el monumenta, según interpreta P. Gros (2002: 404-405), fue el de convertirlo en el elemento clave de la exaltación del difunto y de la sacralización de la sepultura, aunque seguramente con el tiempo se diluyó su carácter simbólico y pasó a ser sencillamente la solución ornamental adecuada.

Por sus características, este mausoleo se inserta en la tradición de las tumbas turriformes denominadas "edículos de varios cuerpos" características de la época tardorrepublicana, y es contemporáneo de grandes tumbas similares conocidas en Italia, la Galia y el norte de África (von Hesberg 1994: 144-185 y fig. 86; Gros 2002). La composición de la torre, aunque aquí de forma más sencilla en los detalles arquitectónicos, responde a la misma tradición de monumentos turriformes con aediculae superiores que acogen en su interior las esculturas que representan a los difuntos. Estas tumbas desarrollan composiciones muy ricas con detalles arquitectónicos muy elaborados y ostentosos como el mausoleo de los Julios en Glanum (Francia), la tumba de Lucius
Poblicius en Colonia (Alemania) o el mausoleo de Kasserine (Túnez). Las imágenes de los difuntos dentro de estos pequeños templetes corresponden en realidad a la evolución de modelos que tienen sus orígenes en la tradición de las tumbas heróicas (heroa) de los siglos IV y III a. C. en el Asia Menor con soluciones de compromiso entre las torres de influencia persa y los naiskoi griegos. Esta tipología de monumenta fue así el resultado de la creciente voluntad de emulación social y cultural de los más poderosos que vivió su momento de más relevancia a inicios de época imperial (Gros 2002: 399-421).

\section{Pintura y policromía}

La Torre de los Escipiones no nos aporta datos suficientes sobre la posible policromía de sus distintos elementos arquitectónicos y escultóricos. Los dos únicos restos de revestimiento conservados se encuentran en la cara posterior del segundo cuerpo, ocupando muy poca superficie, y en las capas de los dos Atis. Para poder plantear una hipótesis sobre la policromía de la torre podemos fijarnos en aquellas necrópolis de parecida cronología donde los revestimientos se hayan podido conservar. En este caso nos sirven de referencia las necrópolis bien estudiadas de Pompeya (Kockel 1983) y del Vaticano (Mielsch 1986). También tenemos en cuenta las pinturas del cuarto 


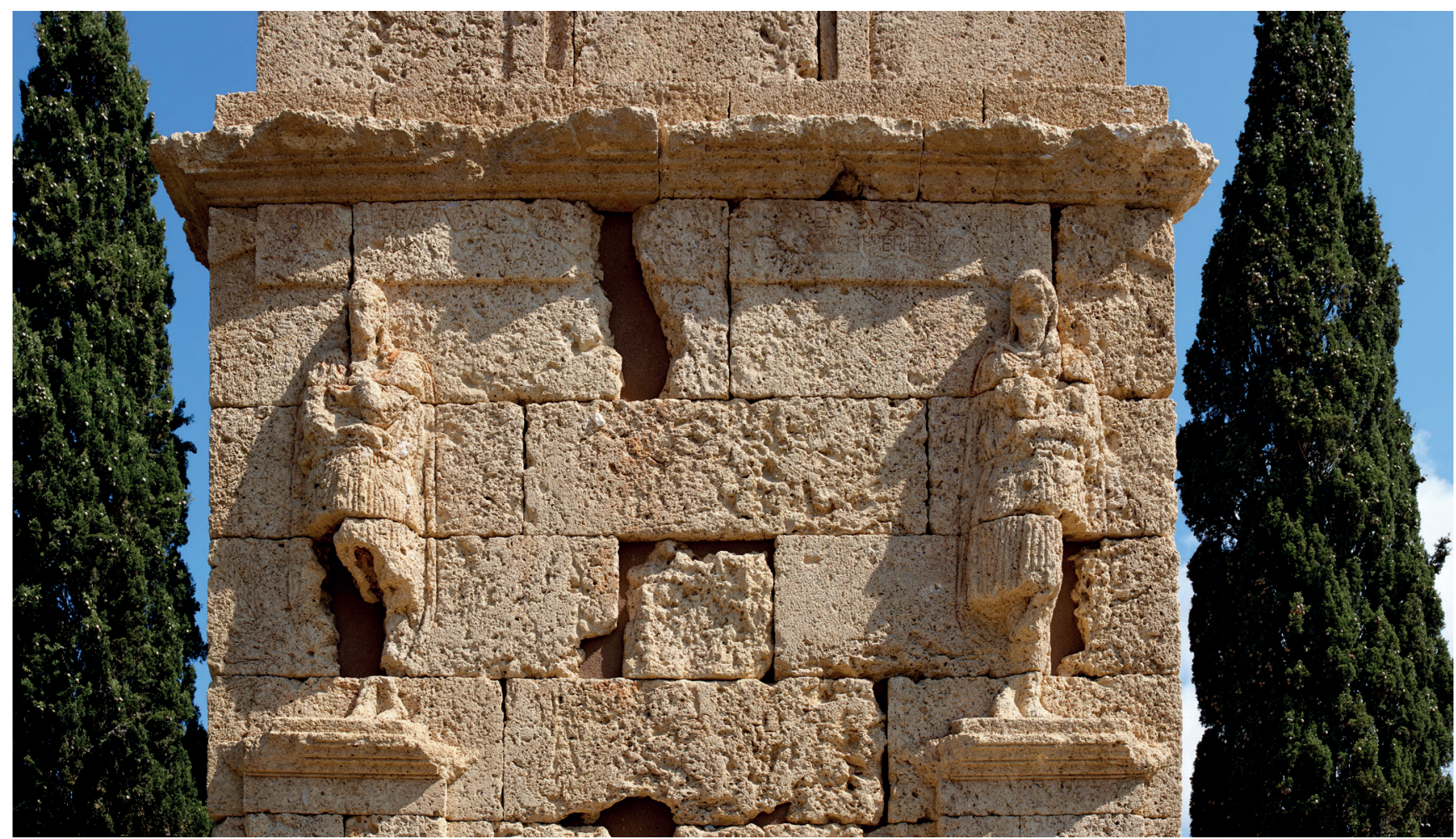

Figura 9. Detalle del aspecto actual de la torre con las dos imágenes funerarias de Atis bajo la gran tabula epigráfica conteniendo el carmen funerario. En el centro del monumento se aprecia con claridad el sillar central recolocado para tapar el agujero producido por la extracción de la lápida del sepulcro.

estilo pompeyano, que coinciden por cronología con la construcción del monumento.

Las características comunes que podemos identificar son el uso del rojo en el primer tercio de los cuerpos, recurso habitual sobre todo para los fustes de columnas. El enmarcado de los planos con una cenefa o línea, así como el perfilado de los elementos arquitectónicos. Teniendo en cuenta la sencillez de la construcción en comparación a los grandes ejemplos antes citados, no podemos suponer una decoración pictórica excesivamente elaborada. Mantenemos así la coherencia entre el conjunto de elementos ornamentales del monumento.

En cuanto a los relieves, tanto de los cónyuges en el nicho superior como de los Atis inferiores no plantean grandes dudas. Uno de los elementos que caracteriza a los Atis es el gorro frigio de color rojo, así como la capa que los cubre también en rojo superpuesta a sus túnicas y bracae. No podemos entender la fachada frontal de este sepulcro sin desarrollar las dos imágenes protegidas por un nicho del cuerpo superior hoy reducidas a simples siluetas. Pudo tratarse quizás de dos hermanos pero parece más lógico que se trate de la representación de una pareja de cónyuges. Siendo Tárraco una colonia romana las vestimentas de ambos difuntos corresponderían a las de la clase privilegiada. El varón portaría una toga blanca mientras que la vestimenta de su esposa sería una stola cubierta con una palla. Las representaciones de personajes como las que aparecen en las pinturas murales de la Villa de los Misterios en Pompeya (Italia), nos dan una idea aproximada de cómo podrían estar ambos representados y una posible combinación de colores de sus telas. Como color de fondo del nicho hemos optado por la habitual solución del azul egipcio. Los nichos laterales, apenas esbozados en relieve sobre los sillares, y que hemos representado vacíos, pudieron quizás haber sido tan solo ligeros relieves de terracota policromados. Su función habría sido representar a las sucesivas generaciones del sepulcro familiar.

\section{El entorno inmediato y la situación jurídica del sepulcro}

No tenemos datos arqueológicos actuales sobre las inmediaciones de la torre que nos permitan reconstruir el entorno. Solamente nos da alguna idea el descubrimiento ocurrido en 1802 por motivo de unas obras en la carretera de Barcelona y que fue ilustrado por Laborde (1806, 27, xuv). Se trataba, entre otros, de dos sillares unidos por piezas metálicas que contenían un vaso de vidrio con otros elementos en su interior. Según Albiñana y Bofarull (1849: 185) se encontró "en el acto de demoler un paredón, de que subsisten aun parte de sus cimientos". Y según el viajero Laborde $(1806,27)$ "En retirant la terre du pied du tombeau, on découvrit des ruines de constructions antiques".

No podemos determinar la antigüedad de estas construcciones en las que se encontraba el hallazgo funerario, ya que no sabemos si los sillares sellados 
fueron encontrados en su posición primaria. Aun así sabemos que los espacios laterales de las vías romanas eran el lugar obligado de los enterramientos y por eso estaban ocupados por todo tipo de sepulturas, grandes y pequeñas. Los grandes sepulcros, individuales o colectivos, de familias privilegiadas, como debe ser en este caso, precisaban normalmente recintos delimitados para la celebración privada de las festividades anuales dedicadas a los difuntos. Por esta razón hemos propuesto rodear la torre por un pequeño recinto murado a modo de peribolos. Esta delimitación, de la que no tenemos constancia arqueológica en nuestro caso, se hace igualmente imprescindible en la hipótesis de reconstrucción dada la importancia de su carácter simbólico.

Los hallazgos arqueológicos antes citados acreditan que la torre se situaba como una más de las tumbas singulares de una necrópolis extendida junto al paso de la Vía Augusta donde se iban yuxtaponiendo los recintos y sepulcros de diferentes familias (Cid 1947). Un ejemplo sería el pedestal funerario del sevir $L$. Lucretius Nicephorus, encontrado junto a la torre según Pons d'Icart y actualmente depositado en el cercano Mas Rabassa (RIT $920=$ IRAT $12=$ CIL $\left.\mathrm{II}^{2}, 14,2304\right)$.

Sabemos que los terrenos dedicados a las sepulturas estaban regidos por un régimen jurídico específico. Las parcelas suburbanas dedicadas a usos agrícolas o de vivienda podían ser compradas y cambiar de funciones sin mayores problemas pero una necrópolis romana era ante todo una res religiosa, un espacio sagrado destinado a albergar a perpetuidad los restos de los antepasados en sepulchra puestos bajo la protección directa de los dioses Manes, garantes de su seguridad y sagrada inviolabilidad. La disciplina de las sepulturas quedaba pues en manos de las normas de los pontífices (De Visscher 1963; Lazzarini 1991; 1997). Los iura sepulcrorum formaban así el conjunto de normas legales que velaban por el derecho y deber de los herederos de velar por los sepulcros familiares (ius sepulcri), garantizar el acceso a los mismos (iter ad sepulcrum), controlar las nuevas deposiciones (mortuum inferre) e impedir por todos los medios los enterramientos ilegítimos (actio violati sepulcri).

Un trabajo de Monika Verzar-Bass (1998) fue dedicado a los grandes mausoleos de la nobleza romana construidos en los horti y en las villae. Se inicia con el ejemplo famoso del sepulcro de Tullia, la hija fallecida de Cicerón enterrada en la villa paterna de Tusculum en el 45 a. C., y que su padre quería complementar con un templete en uno de los horti de los alrededores de Roma, encargando a su amigo Atico la búsqueda y compra de la parcela más conveniente (Cic. Ep ad Att. XII, 18 ss.). La razón, una vez más, se limitaba a la necesaria frecuentación y buena visualización del monumento que garantizara su celebritas y que aparentemente no podía cumplirse de forma satisfactoria en alguna de las diferentes propiedades rurales del poderoso senador. También a la necesidad de que el sepulcro quedara a salvo de posibles compraventas posteriores.

A través del análisis de diferentes ejemplos de grandes mausoleos tardorrepublicanos se comprueba ciertamente la costumbre de los poderosos del ente- rramiento in villa mediante monumentos fúnebres en ocasiones gigantescos, cuyos restos han sobrevivido al paso de los siglos, o bien la elección de un hortus suburbano, vecino a una gran vía pública que asegurara la frecuentación en el entorno de una gran ciudad. En el caso de la Torre de los Escipiones se trató ciertamente de un sepulcro in villa pero eligiendo cuidadosamente un lugar visible desde el vecino mar, inmediato a la Vía Augusta y precisamente en el punto en que en un viaje de norte a sur se contempla por primera vez en el horizonte el perfil de la ciudad de Tárraco / Tarragona. El grabado romántico de Laborde recoge perfectamente esta situación a la vez privilegiada y singular.

Olvidando la leyenda y tradición sobre su nombre, la torre fue simplemente un monumentum, el gran sepulcro de una familia privilegiada con propiedades en la zona, que escogió para su morada eterna el lateral de la Vía Augusta. De esta manera, los viatores, caminantes y viajeros que utilizaban la calzada, podían leer el epitafio y aseguraban así la memoria aeterna de los difuntos. Recordemos que según las creencias romanas, su vida feliz en los Campos Elíseos solo quedaba asegurada si perduraba en la tierra su recuerdo, eternamente, y para ello no había un lugar mejor para situar una tumba que al lado de la vía más importante, la de mayor tráfico.

\section{Releyendo su decoración...}

En un contexto funerario como el de la Torre de los Escipiones, las dos estatuas de Atis pensativos representan ante todo un carácter apotropaico, protector, como genios funerarios de la reencarnación porque su mito, ligado a los festivales de la diosa Cibeles, implicaba cada año su muerte sangrienta seguida de forma inmediata por su resurrección con ocasión de sus festivales específicos celebrados entre los días 15 y 27 de marzo. La iconografía de estas imágenes funerarias de Atis fue siempre muy precisa y podemos conocerla gracias a la gran tarea realizada por J. M. Vermaseren publicando en Ed. De Brill a partir de 1977 los nueve volúmenes del Corpus Cultus Cybelae Attidisque (CCCA) seguidos, ya como obra póstuma, de la voz Atis del LIMC (Vermaseren y De Boer 1986); también, por ejemplo, en otros, con el trabajo complementario de C. M. Cosi (1982) para el carácter mistérico de los ritos relacionados con Atis.

La iconografía de Atis conduce siempre directamente al sur de Asia Menor. En la lejana Cilicia, encontramos imágenes de Atis prácticamente idénticas a las de la torre en el llamado sarcófago de Hércules de la necrópolis oriental de Pergé, hoy en el Museo de Antalya. Se trata de un gran sarcófago de mármol del siglo II dC, con una altura de 1,65 m, ricamente decorado con forma de templo períptero con sucesivas imágenes de los trabajos de Hércules en los laterales (con la curiosidad iconográfica de que el héroe va envejeciendo en su realización). En el frontal, el frontón del templo aparece decorado con una imagen de Gorgona y la puerta de acceso a la tumba I templo aparece flanqueada por dos Atis de nuevo sobre pedestales en esta ocasión circulares (Antalya 1989: 66-67). Esculturas de Atis en idéntica posición 


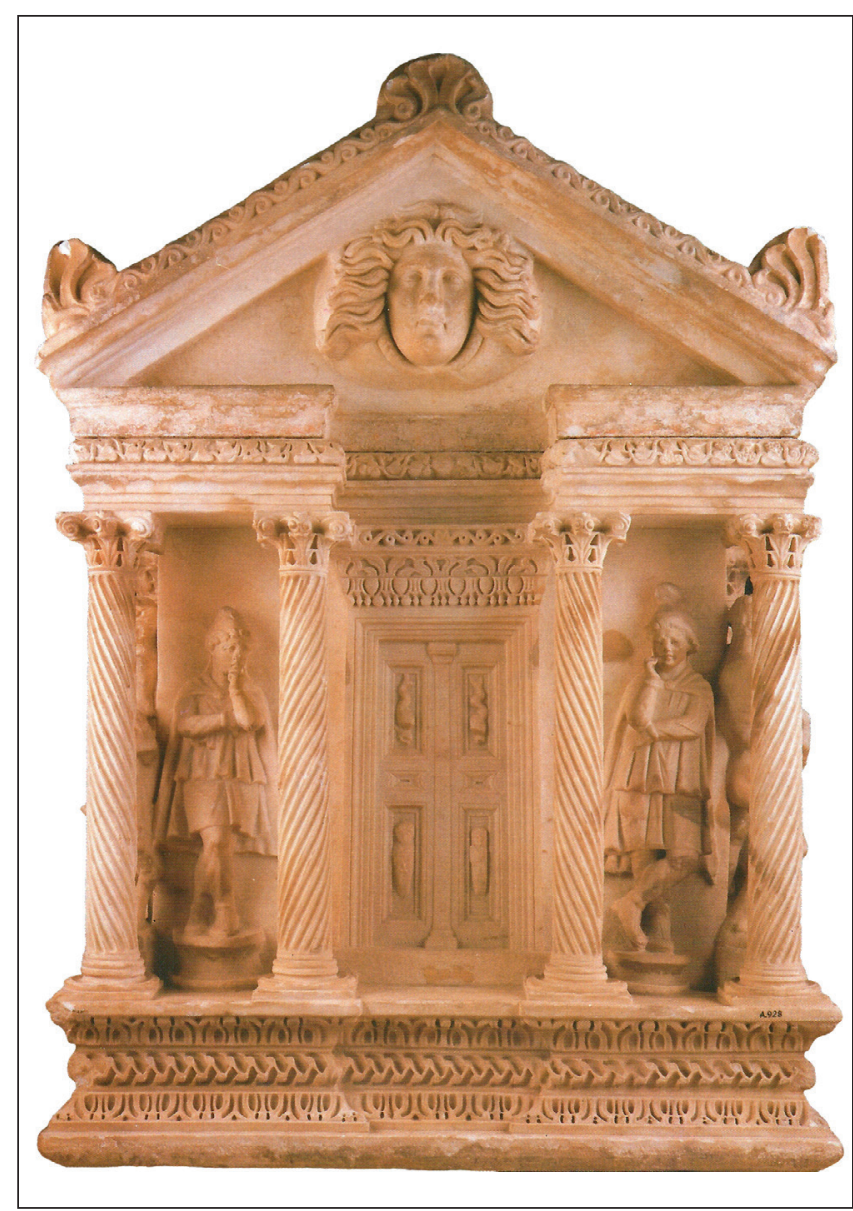

Figura 9b. Frontal del sarcófago de los trabajos de Hércules. Necrópolis Este de Pergé (Asia Menor, Turquía). Museo de Antalya. Ver la posición idéntica a la vez protectora y vigilante de los dos Atis a ambos lados de la puerta.

eran habituales desde el siglo I d. C. (Koppel 1993; Vermaseren y de Boer 1986: n. ${ }^{\circ} 3$ Roma, 9 Sevilla, 26 Nyon, 46 Nápoles, 92 Viena, 117 Herculanum).

Pero fue precisamente esta diferencia de fechas entre las apariciones iconográficas habituales de Atis por todo el mundo romano y la fecha anterior estimada para la torre lo que llevó a Paul Zanker (2002) a proponer una lectura diferente simplemente como dos bárbaros orientales en actitud vencida, la iconografía que conocemos bien en la Galia y en la propia Tárraco en relación con las victorias de Augusto. Era una observación pertinente por parte del máximo especialista sobre el uso que la ideología romana hacía de las imágenes, especialmente en los inicios de la nueva edad de oro de Augusto. Pero quince años después estamos ya en condiciones de leer en Tárraco todas estas imágenes de una forma mucho más precisa.

En el año 2011 trabajamos ya el tema de los relieves tarraconenses con bárbaros cautivos aparecidos en lo que ahora sabemos fue un chalcidicum de culto imperial situado entre la basílica forense y el capitolio de la colonia (Vivó et al. 2011; Mar et al. 2015: 260-280). Gracias al trabajo de Marc Lamuá (2009) sobre los relieves del Arco de Carpentras, en la Galia, podemos definir con precisión estos bárbaros aislados o en parejas unidos a trofeos como un sistema iconográfico de representación del mundo, ya fuera por provincias vencidas como la Galia e Hispania del trofeo de Saint Bertran de Comminges (Boubé 1996) o bien como los extremos del Imperio en Carpentras y Tarragona a través de dos trofeos diferentes, cada uno con una pareja de bárbaros encadenados. En uno de los trofeos, un bárbaro oriental con bracae, gorro frigio y doble hacha representaría el reino cliente de Armenia, el Este, el extremo oriental del Imperio; a su lado, un bárbaro con falcata y un manto de lana (en Carpentras) o una túnica corta ceñida (en Tárraco) sería un galaico o un astur, el extremo occidental del Imperio, el Oeste. Sigue en la cara opuesta del Arco de Carpentras un segundo trofeo con un bárbaro barbudo con un vaso metálico con cuello de ánade, sin duda un germano, es decir el Norte, aparejado con otro hombre, con túnica fina y pañuelo en la frente, acompañado por una pequeña sítula de seno isíaca. Esta pieza característica nos permite identificarle con seguridad como un egipcio representando el Sur (Lamuá 2009).

A pesar de la sugerencia de Zanker, nada hay en las dos imágenes de la Torre de los Escipiones que nos dirija hacia esa iconografía contemporánea de la Victoria Augusta. Falta el trofeo, faltan las armas y faltan los objetos alegóricos. Tampoco en los trofeos citados los cautivos se repiten nunca sino que se complementan entre sí (ya sea por parejas de sexo diferente o por naciones). $\mathrm{Y}$ sobre todo, como conclusión, es necesario reconocer que en su aspecto, forma, posición y vestuario, los dos jóvenes orientales de la torre no son dos pueblos vencidos sino que representan con seguridad al pastor frigio Atis. Esto es así en base a su posición iconográfica, un gesto característico en meditación que agrupa tres elementos diferentes: piernas cruzadas, brazos cruzados y mano derecha sobre el mentón. No existe duda posible. Pero llegados a este punto resulta importante que precisemos la datación del monumento $\mathrm{y}$ en base a la misma podamos justificar la presencia de Atis en Tárraco.

\section{Datando el monumento...}

La datación de la torre puede ser aproximada a partir de dos evidencias complementarias como son la datación paleográfica de la inscripción de la tabula ansata y el hecho de tratarse de un gran monumento realizado en piedra local estucada. G. Alföldy (RIT 921 y CIL $\left.\mathrm{II}^{2}, 14,2306\right)$ insiste en reconocer para la paleografía de la inscripción poética una datación en plena época augustea con la que está de acuerdo Gómez Pallarés (2002: 116) admitiendo que puede prolongarse hasta época de Tiberio. Una fecha en la que también estuvo de acuerdo E. Koppel (1993) al analizar las imágenes de los dos Atis.

Una fecha en torno al cambio de Era concuerda con el uso de la piedra local estucada para el monumento que nos situaría en fechas anteriores a la "marmolización" de la capital provincial a partir de la construcción del templo de Augusto en época tiberiana. Recordemos que en los años en torno al cambio de Era fue construido el gran teatro de la colonia utilizando exclusivamente la piedra local del 
Médol estucada y pintada (Mar et al. 2011). Pero una vez construido y admirado el gran templo de Augusto realizado enteramente con mármol de Carrara, tan solo una o dos generaciones más tarde, la dignitas de una familia importante de Tárraco habría exigido por el contrario un edificio fúnebre levantado o como mínimo placado con la "piedra de Luna", el ya imprescindible mármol de Carrara. Lo recordaba en la Galia, el epígrafe funerario de un notable de gran riqueza conocido como el testamento del lingón (Langres; CIL XIII, 5708, copiado en un pergamino medieval):

Quiero que la capilla funeraria que he mandado edificar sea acabada según la planta que he dado, de manera que haya una exedra en la que se sitúe una estatua mía sentado, hecha en mármol, en la mejor piedra de ultramar, (y que también se coloque) una estatua de bronce, utilizando láminas de la mejor calidad posible, que sea de alta por lo menos 5 pies $(1,5 \mathrm{~m})$; que se coloque bajo la exedra una litera y dos banquetas a los lados en piedra de ultramar; como aditamentos para los días en que la capilla funeraria se abra que se coloquen dos cobertores y dos almohadones y dos manteles de mesa y una túnica; delante de este edificio se levantará un altar en piedra de Luna, de la mejor calidad posible, esculpida con el mejor arte, en la cual descansarán mis restos, y que este edificio sea cercado con piedra de Luna de manera que pueda abrirse y cerrarse, que este edificio y el huerto con el estanque sean mantenidos por mis libertos Philadelphus y Verus...

\section{Cultos orientales en la Tárraco tardorre- publicana}

La decoración escogida para el frontal de la torre otorga una absoluta prioridad escénica a los dos Atis funerarios que enmarcan los tituli funerarios y que solo podían entender los viandantes familiarizados con los cultos de Cibeles, la Magna Mater, gran diosa madre de Anatolia, y de Atis, el joven y atractivo pastor natural de Frigia convertido en su sirviente. Hemos pues de poder explicar las razones de esta decoración. Empezemos para ello por la propia Roma.

En el año 204 a. C. los romanos estaban abocados al pleno esfuerzo final tras catorce años de guerra continua en la Segunda Guerra Púnica, todavía con Aníbal instalado en el sur de Italia. Después de sufrir una serie de raros prodigios que incluyeron lluvias de piedras, los libros sibilinos y la consulta al propio oráculo de Delfos aconsejaron a los romanos enviar una embajada al reino de Pérgamo en busca de la sagrada piedra negra del monte Ida, el sagrado monte troyano. Se trataba de un trozo de meteorito representando a la gran Magna Mater, la diosa invocada desde la Prehistoria en Asia Menor y luego también en Grecia por su poder sobre la naturaleza y por su carácter de suprema protectora de sus devotos (Vermaseren 1977; Burkert 1991). Gracias a la intervención milagrosa de la piadosa vestal Claudia Quinta que consiguió desencallar el barco de las arenas del bajo Tíber, la piedra sagrada pudo llegar a Roma y ser instalada de forma provisional en el templo de la Victoria. Más tarde, acabada la guerra contra Cartago en el 201 a. C. se pudieron acelerar las obras de su templo inaugurado el 9 de abril del año 191 a. C. (Vermaseren 1977; ver síntesis en Turcan 1989).

Pero a pesar de su fama y su poder demostrado, los ciudadanos de Roma no participaban en los cultos orgiásticos y violentos de esta deidad anatólica, únicamente asistían como espectadores a sus grandes festivales anuales en los meses de marzo y abril. Los sacerdotes de la Magna Mater eran siempre extranjeros ya que uno de los extraños rituales de muerte y resurrección implicaba la pasión de la diosa por el joven y bellísimo pastor frigio Atis, nacido junto al río Sangario, que había roto su promesa de castidad a la diosa al enamorarse de una ninfa. Atis encontró la muerte al castrarse a sí mismo con un pedernal debajo de un pino en un ataque de locura pasional. En su imitación también se castraban sus sacerdotes, los galli. Catulo dedicaría uno de sus carmina, el 63, al mito de la diosa con un texto repleto de hostilidad y Ovidio (Fast. IV, 179 y ss.) intentó explicar a sus conciudadanos la lógica del mito que obligaba a la emasculación ritual de los sacerdotes (Vermaseren 1976; 1977; ver también la útil síntesis actualizada de Alvar 2001: 67-73). En el puerto internacional de Ostia Antica, la Magna Mater contaba con un extenso santuario junto a una de las puertas de entrada a la ciudad incluyendo un recinto específico dedicado a Atis. Tuvimos oportunidad de estudiar este santuario a lo largo de varias campañas dirigidas por R. Mar entre los años 1995 a 1997. Sus fases estratigráficas y estructurales corresponden casi por entero a la época imperial romana pero los abundantes hallazgos de esculturas y epígrafes lo convierten en lugar de referencia junto a sus homólogos romanos de las colinas palatina y vaticana (Vivó 1998).

El rito se desarrollaba a lo largo de seis días del 15 al 27 de marzo a cargo de distintas cofradías. Los cannofori iniciaban el ciclo llevando al santuario las cañas del río Sangario, morada de Atis. El día 22 se introducía también un pino por los dendrophori decorándose sus ramas con banderolas fúnebres. Seguía un día de abstinencia que precedía la trágica muerte de Atis recordada el 24 de marzo, el dies sanguinis, en el que algunos iniciados imitaban trágicamente la emasculación del joven pastor. Inmediatamente seguía un día de fiesta descontrolada, las Hilaria, celebrando la resurrección de Atis y su nueva unión al séquito de la diosa, luego un necesario día de reposo, requietio y por último una gran procesión para lavar en un río cercano la imagen de la diosa Cibeles. Después de su muerte violenta y terrible Atis lograba alcanzar la ansiada resurrección incorporándose eternamente al séquito de la diosa como pasajero de su famoso carro tirado por leones tal como nos muestra la famosa patera de Parabiago, hoy en el Museo de Milán, joya de la gran platería del siglo IV. Por el contrario, las grandes Megalesia dedicadas a Cibeles entre los días 4 a 11 de abril eran ya actos públicos abiertos a los ciudadanos que incluían básicamente banquetes, espectáculos escénicos y carreras de carros recordando la llegada a Roma en el año 204 de la piedra negra desde Pesinunte.

Tal era la razón por la cual Atis se convertía en un simbólico guardián funerario (Cosi. Era un ejemplo 


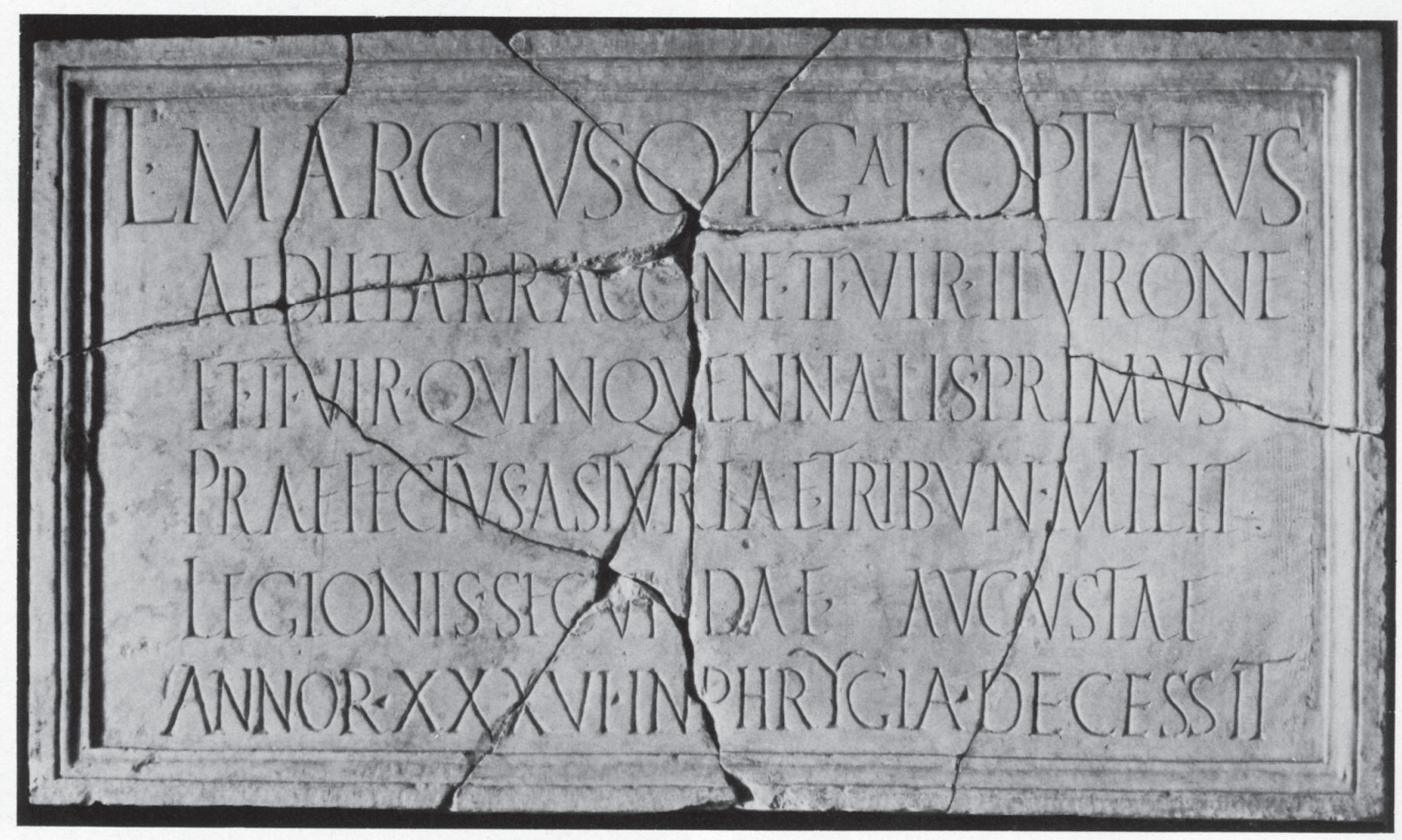

101

Figura 10. Lápida del cenotafio del magistrado y eques L. Marcius Optatus encontrada en Iluro, hoy en el Museo de Mataró (IRC 01, lám. XXXVI).

más del carácter complejo de los ritos que llamamos mistéricos y que en su conjunto (Magna Mater, Deméter y Coré, Isis y Serapis, Mitra) significaban una búsqueda personal de la curación primero y de la inmortalidad después. Esto se producía a través de iniciaciones de los devotos en comunidades siempre cerradas o incluso secretas, con festivales repetidos anualmente que favorecían la captación de nuevos devotos y sacrificios especiales en el caso de la Magna Mater como los taurobolia y criobolia, bautismos rituales de los fieles con la sangre derramada de un toro o un macho cabrío degollados sobre el devoto que debían repetirse en períodos de cada veinte años y que se hicieron habituales a partir del año $160 \mathrm{~d}$. C. (Burkert 1991). Unos cultos no obstante que la epigrafía siempre nos muestra ofrendados in honorem domus divinae, es decir relacionados con homenajes a la salud de la casa imperial (Liverani 2008). Después de que el emperador Claudio permitiera la apertura de los cultos mistéricos, el santuario de Cibeles en el Palatino se complementaría así con el nuevo gran santuario de los dioses frigios o Phrigianum vecino al circo de Calígula, donde más tarde se levantó la basílica de San Pedro. Ambos santuarios quedaban unidos en la gran procesión de las Hilaria que acompañaba a las imágenes de Cibeles y Atis de nuevo juntas en el gran carro de la diosa tirado por leones (Pensabene 2010).

Incorporados así a las festividades tradicionales del año romano, los cultos de Cibeles y Atis, permanentes en las provincias orientales, se hicieron también tremendamente populares tanto en las Hispanias como en la Galia a lo largo de los siglos II y III d. C. (Turcan 1989; Alvar 2001).

Ahora bien, estos cultos mistéricos en absoluto eran frecuentes en el ámbito provincial hispano doscientos años atrás, durante los siglos il y I a. C. Contamos ya con algunas evidencias diversas de su introducción siempre a través de los grandes puertos mediterráneos y normalmente en contacto con la actividad comercial de los mercaderes marítimos. Este sería el caso de la introducción en la lejana Emporion a fines del siglo II a. C., de un conjunto de esculturas de los dioses alejandrinos Isis, Serapis y sus acompañantes Agathos Daimon y Harpócrates, por parte de Numas, un comerciante de Alejandría que trasladaría hasta nuestras costas un conjunto de estatuas realizadas en la isla de Delos para levantar un santuario a sus dioses patrios, patrones de la navegación... y de los negocios (Ruiz de Arbulo y Vivó 2008). En Carthago Nova la prioridad en los grandes cultos fue siempre lógicamente la de los grandes dioses tutelares púnicos como Eschmun Asklepios, o Tanit - Dea Caelestis. En lo alto de la colina del Molinete en el lugar antaño ocupado por el gran palacio de los Bárquidas, se levantó en el siglo I a. C. un santuario dedicado a Atargatis, la Dea Syria, asimilada también a la feno-púnica Astarté (Ramallo y Ruiz Valderas 1994; Uroz 2005).

Desgraciadamente no tenemos más evidencias de las costumbres religiosas de la Kese / Tárraco tardorrepublicana que el relieve de la Minerva en la torre de la muralla que presidía la primera muralla del gran recinto militar romano, complementada con 


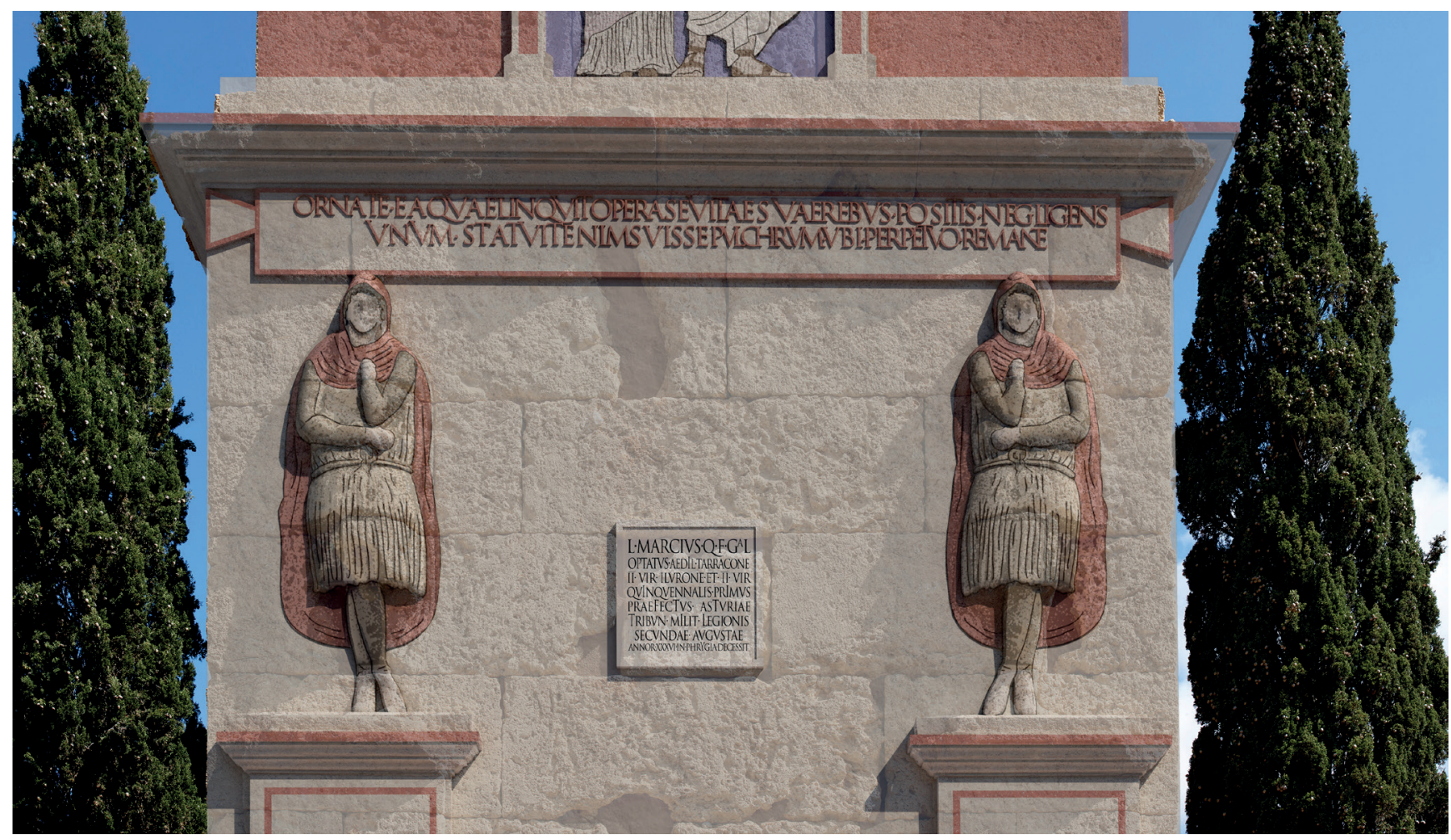

Figura 11. Propuesta de restitución del frontal de la Torre de los Escipiones, identificada como el cenotafio tarraconense del eques L. Marcius Optatus.

el grafito de un Manios Vibios a la etrusca Minerva aparecido en una de las aspilleras de la torre. Desde luego sabemos que la ciudad fue junto a Carthago Nova uno de los puertos principales de la costa hispana mediterránea y que estaban activos en la ciudad diversos grupos de libertos y esclavos actuando como magistri de distintas societates y sodalitates sacrae como las que conocemos en Delos, instaladas en la ciudad desde fines del siglo II a. C. controlando las grandes obras públicas y el gran comercio marítimo. Los dueños de estas grandes societates, hombres de negocios con intereses repartidos por todo el Mediterráneo, permanecían en sus ciudades de origen y enviaban en su lugar a esclavos y libertos de confianza para hacerse cargo de las contratas en ultramar. Por esa razón los nombres que resultan mayoritarios en estas primeras inscripciones latinas tarraconenses son sobre todo esclavos y libertos (RIT 5-11; Mar y Ruiz de Arbulo 2011: 257-258 y 287-290).

La servidumbre no estaba reñida con la alta capacidad cultural, sobre todo en el caso de esclavos procedentes de Grecia, y con la asunción de trabajos de gran responsabilidad. Así pues no sería descartable que a través de ese colectivo de libertos y esclavos llegara en fecha temprana a la ciudad el culto de la Magna Mater. Aun así, creemos contar con otro indicio que nos permitiría entender de una forma más concreta la presencia de los dos Atis en este sepulcro para esa cronología tan temprana en torno al cambio de Era.

\section{... y a su dedicante}

La tabula superior con el carmen epigráfico describe el sepulcro como un cenotafio, el sepulcro simbólico de alguien que murió en otro lugar pero que ya fuera por disposición testamentaria (opción A), o bien por el homenaje anónimo de un pariente muy cercano (opción B), se ordenó levantar el monumentum. Tanto por las dimensiones y decoración del sepulcro como por el lugar escogido junto a la Vía Augusta, en lo alto de un pequeño collado con vistas al mar y a la ciudad en la distancia, podemos asegurar que se trataba de una de las familias principales en la colonia tarraconense.

En este contexto, y por una de esas extrañas coincidencias de la investigación, creemos contar con un firme candidato para la promoción de este monumento. Se trata de un viejo hallazgo epigráfico casual en la ciudad de Mataró producido ya en 1814: una placa moldurada de mármol blanco, de dimensiones medianas $(60,5 \times 103,5 \times 6,7)$ hoy rota en 12 fragmentos, y conservada en el Museo Comarcal del Maresme. Es esta una pieza conocida de antiguo (CIL II, $4616=$ ILS 6948) cuya historiografía puede consultarse en el completo estudio que le dedicaron G. Fabre, M. Mayer e I. Roda (IR Mataró 5; IRC 01, 101). Por su buen estado de conservación, la transcripción no presentaría problemas:

L(ucius) Marcius Q(uinti) f(ilius) Gal(eria tribu) Optatus / aedil(is) Tarracone II vir Ilurone / et II vir quinquennalis primus / praefectus Asturiae tribun(us) milit(um) / legionis secundae Augustae / annor(um) XXXVI (triginta sex) in Phrygia decessit, 
"Lucio Marcio, hijo de Quinto, inscrito en la tribu Galeria, edil de Tárraco, duumvir de Iluro y primer duumvir quinquennal, prefecto de las Asturiae, tribuno militar de la legión II Augusta. Ha muerto en Frigia a la edad de treinta y seis años".

Los epigrafistas han discutido la época de este personaje, ya fuera en los años en torno al cambio de Era, en plena época de Augusto, o bien entre los años 50 y 80, a fines del mandato de Nerón y en época de los Flavios. O incluso más tarde: E. Hübner, en CIL II, 4616, no dudaría en llevar la inscripción al siglo II por criterios paleográficos.

Fabre, Mayer y Rodà (1984: 149) proponen situar la carrera de Marcio entre los años 50 y 75, apoyándola en la reorganización provincial debida al edicto de latinidad de Vespasiano. Marcio habría ocupado su cargo de edil tarraconense en torno a los treinta años, para ser encargado acto seguido de reorganizar con un nuevo censo los grupos sociales del municipio iluronense y continuar una carrera de milicias propias del orden ecuestre como praefectus Asturiae, ya fuera en relación con la revuelta atestiguada entre los años 55 y 60 bajo Nerón, o bien como especialista en censos encargado de la reorganización social de la población del conventus Asturum, en relación con el nuevo censo provincial de los flavios de los años 73/74. Marcio Optato continuaría sus dos años de prefectura civil con un nuevo cargo militar como tribuno de la legión II Augusta estacionada en esas décadas en Britannia (Le Roux 1982: 101-103, al que siguen Fabre, Mayer y Rodà 1984: 149 y nota 124). Pero con este cursus no se entienden bien las razones para la marcha y muerte de Marcio hasta la lejana Frigia si estaba sirviendo en Britannia, ni por qué no se menciona cuál fue su nueva y última responsabilidad militar ecuestre que le condujo hasta allí.

Existe sin embargo una interpretación cronológica diferente que ha sido defendida por Géza Alföldy (1983) siguiendo la opinión anterior de Ritterling, Pflaum y Devijver. Como siempre, la lectura de los argumentos que dan los distintos especialistas puede tender a confundir, pero en este caso creemos que la lectura del sabio húngaro permite entender mejor el cursus honorum de Marcio Optato, en las tres fases de su promoción como magistrado urbano, especialista en censos e integrante de las milicias del orden ecuestre (Caballos 1999).

Se trataría para Alföldy de un joven edil tarraconense en los años previos al cambio de Era, ¡el primero conocido en la nueva colonia!, contemporáneo del propio Augusto en su estancia en la ciudad en los años 26 y 25 a. C. Sería pues un joven brillante de familia ecuestre al que quizás el propio emperador, tras conocer su comportamiento como edil de la colonia, decidiera personalmente encargarle controlar la formación del nuevo orden social del pequeño pero estratégico oppidum civium romanorum de Iluro como duumviro quinquenal. Iluro fue una nueva ciudad romana en la costa del Maresme, actual Mataró, con toda probabilidad un municipio que sustituyó a un importante asentamiento ibérico anterior. La cercanía de Baetulo, ciudad igualmente de rango municipal, hacía necesario el control de la división parcelaria y los límites territoriales respectivos. De esta forma,
Marcio Optato como duumviro quinquenal habría actuado en la práctica como magistrado fundador de Iluro, donde repetiría cargo al año siguiente ya como simple duumviro probablemente acabando todo el proceso de reorganización social.

Su prefectura de Asturiae para Alföldy se produciría de forma inmediata y tendría lugar muy poco después de ser aplastada la revuelta astur en el año 25 a. C. Se relacionaría en este caso con la primera reorganización de los territorios al norte del río Duero en la que entonces era considerada la nueva provincia de la Hispania transduriana. Eran tierras sometidas a una férrea represión militar pero que precisaban igualmente ser reorganizadas de nuevo para la paz. Una tarea que fue encomendada a Marcio Optato ahora ya con una responsabilidad propia del orden ecuestre. En esas fechas tan tempranas su siguiente nombramiento como tribuno de la legión II Augusta está plenamente justificado por ser esta legión una de las estacionadas en ese flanco oriental de la cornisa cantábrica durante la guerra astur, donde permanecería durante años en sus bases de Segisama y en el entorno de Iuliobriga antes de ser enviada urgentemente al Rin en el año 10 d. C., tras el desastre el año anterior de la selva de Teotoburgo (Rodríguez González 2003: 85-87). Las etapas de la carrera de Optatus se pueden situar así en un marco histórico muy preciso.

En último lugar, cree de nuevo Alföldy, su muerte temprana en Frigia, ¡la patria de Atis, añadimos nosotros ahora!, con solo treinta y seis años, se pudo producir ocupando un nuevo cargo de confianza que le llevaría a acompañar al propio Augusto en su viaje a Oriente de los años 20-19 a. C. Un viaje que llevó al emperador de paso por Samos, Grecia, Asia y Siria y que incluyó contactos políticos de alto nivel con los enemigos partos para conseguir la devolución de las águilas tomadas a las legiones de Craso en Carras.

La carrera ecuestre de Marcio se encuentra pues en discusión entre ambas dataciones, obligando a J. M. Ojeda (1993, ap. 1) a situar su caso en un apéndice eliminando su cursus de la lista prosopográfica del servicio administrativo imperial ecuestre de la Hispania romana. Por nuestra parte creemos más razonable la interpretación de Alföldy que inspira ahora nuestra propuesta de atribución de la torre. Si Marcio Optato, natural de Tárraco y muerto en Frigia, recibió el cenotafio de Iluro al que pertenecía este hallazgo epigráfico, necesariamente hemos de pensar que debió recibir igualmente un segundo cenotafio en la ciudad de la que era originario y donde todavía debía vivir su familia. Su tumba tuvo que ser importante ya que se trata del primer ecuestre que conocemos en la colonia tarraconense. Nuestra interpretación pasa pues por proponer que la famosa segunda lápida extraída de la torre en el siglo Xvi tuviera un texto igual o muy similar al encontrado en Mataró.

De ser así, todos los datos que hemos ido presentando hasta el momento, epigráficos, iconográficos y cronológicos, encontrarían acomodo. La llamada Torre de los Escipiones pasaría a ser el mausoleo tarraconense del eques Lucius Marcius Optatus. Las dos posibles lecturas de la tabula nos permiten imaginarla como la tumba de su familia gracias a 


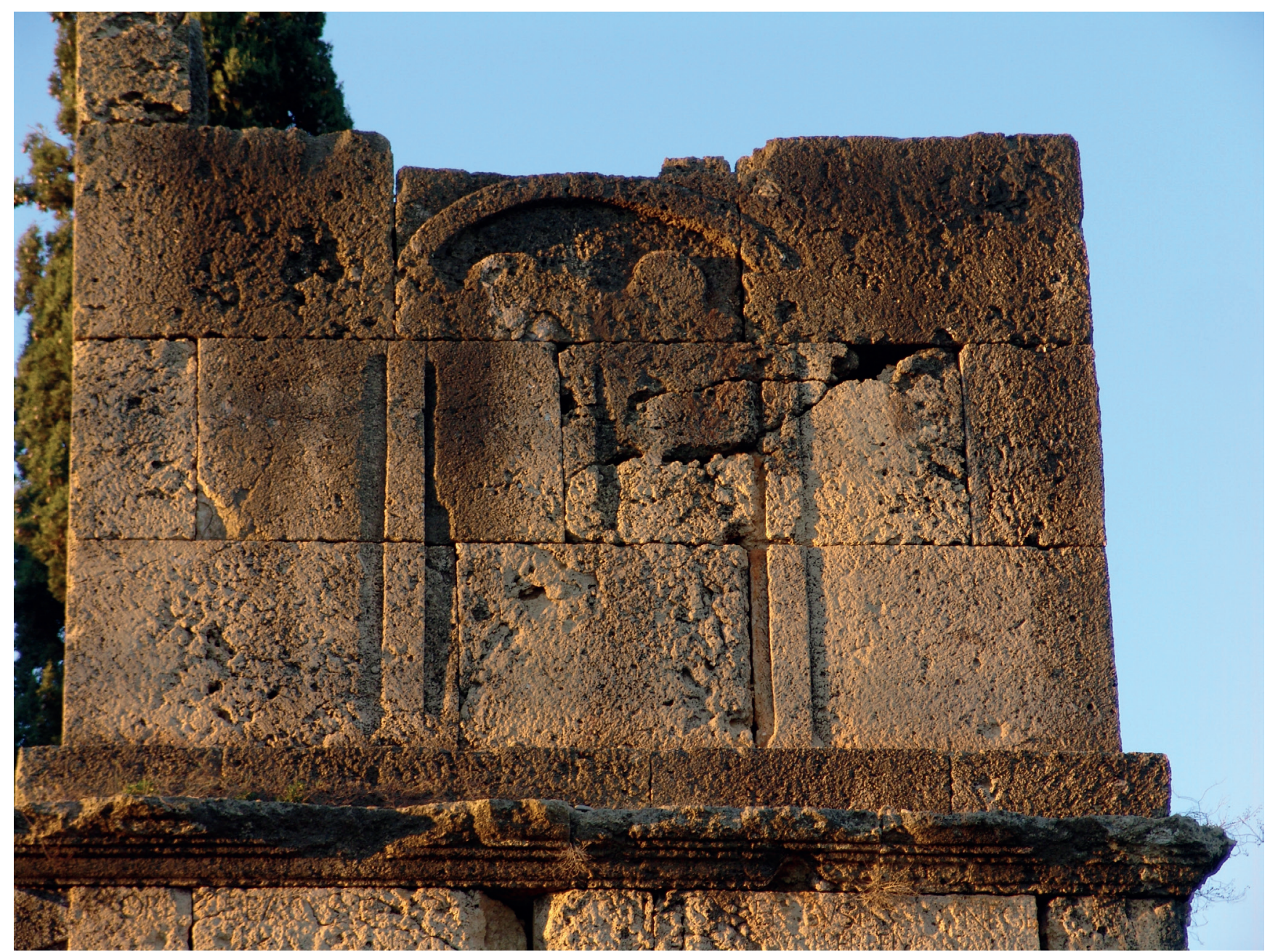

Figura 12. Las dos figuras del nicho superior siguen guardando con ellas el secreto de la identificación exacta de la torre.

un don testamentario propio (según la lectura de Mariner / Mayer, Miró y Perea) o bien su sepulcro individual, levantado quizás por sus propios padres en su memoria y homenaje (según la lectura de Alföldy). Estas variantes llevarían a plantear distintas posibilidades para la pareja representada en el nicho del nivel superior.

El mausoleo, construido un poco antes del cambio de Era, estaría decorado con imágenes de Atis como genio protector de las cenizas del eques, enterradas en la muy lejana Frigia, las tierras de Asia Menor en un sentido amplio, antes de quedar divididas en sucesivas provincias romanas. Ninguna otra imagen podía haber sido mejor escogida para recordar que la tumba era tan solo un cenotafio y que los restos del difunto estaban sepultados muy lejos, faltos por ello del completo ritual necesario para garantizar la deseada memoria eterna. Todo ello quedaría explicado por ese epitafio marmóreo robado y trasladado que proponemos ahora restituir.

¿Quién sabe? Dado que se trata de una pieza extraída en el siglo XVI, quizás su reaparición, si algún día se llegara a producir, nos daría finalmente las claves de la tumba y los nombres de la pareja contorneada en el nicho superior, ya fueran los padres de Marcio, el propio ecuestre con su mujer, dos hermanos o dos descendientes. 
Abad Casal, L., Bendala Galán, M. (1985). Los sepulcros turriformes de Daimuz y Villajoyosa: dos monumentos romanos olvidados. Lucentum, 4: 147-184.

Albiñana, J. F., Bofarull, A. (1849). Tarragona Monumental, o sea descripción histórica y artística de sus antigüedades y monumentos celtas y romanos. Tarragona.

Alföldy, G. (1983). Zur Geschichte von Asturia und Gallaecia. Bemerkunde zu Alain Tranoy, la Galice Romaine. Germania, 61-2: 511-528.

Alföldy, G. (2003). Sociedad y epigrafía en Tarraco. En: Armani, S., Hurlet-Martineau, B., Stylow, A. (ed.). Epigrafía y sociedad en Hispania durante el Alto Imperio, estructuras y relaciones sociales (Madrid / Alcalá de Henares 2000). Alcalá de Henares: 159-176.

Alvar, J. (2001). Los misterios. Religiones "orientales" en el Imperio Romano. Crítica. Barcelona.

Antalya 1989 = DöRTLÜK, K. (1989). Guide des Musees. Antalya. Keskin color. Istanbul.

Aurigemma, S. (1963). I monumenti della necropoli romana di Sarsina. Roma.

Boubé, E. (1996). Collections du Musée Archéologique Departemental de Saint-Bertrand-de-Comminges, 4, Le Trophee Augusteen. Balma.

Burkert, W. (1991). Antichi culti misterici. Laterza. Bari.

Caballos, A. (1999). Preliminares sobre los caballeros romanos originarios de las provincias hispanas. Siglos I-III D. C. En: Rodríguez Neila, J. F. y Navarro, F. J. Élites y promoción social en la Hispania romana. Eunsa. Pamplona: 103-144.

CCCA = Vermaseren, M. J. (1977 y años sucesivos). Corpus Cultus Cybelae Attidisque, vols. I a IX. E. J. Brill. Leiden.

CCCA 1986 = Vermaseren, M. J. (1986). Corpus Cultus Cybelae Attidisque (CCCA), vol. V. Aegyptus, Africa, Hispania, Gallia et Britannia. E. J. Brill. Leiden.

Cid PRiego, C. (1947). El monumento conocido por “Torre de los Escipiones", en las cercanías de Tarragona. Empúries, 9: 137-169.

CIL II ${ }^{2}, 14,2$ = Alföldy, G. (2011). Corpus Inscriptionum Latinarum. Pars XIV Conventus Tarraconensis. Fasciculus Secundus Colonia Iulia Urbs Triumphalis Tarraco. Walter de Gruyter. Berlín / Nueva York.

CIL II ${ }^{2}$, 14, 3 = AlföLdy, G., Niquet, H. (2012). Corpus Inscriptionum Latinarum. Pars XIV Conventus Tarraconensis. Fasciculus Tertius. Colonia Iulia Urbs Triumphalis Tarraco. Walter de Gruyter. Berlín / Nueva York.

CIL II ${ }^{2}, 14,4$ = Alföldy, G., Niquet, H. (2016). Corpus Inscriptionum Latinarum. Pars XIV Conven- tus Tarraconensis. Fasciculus Quartus. Colonia Iulia Urbs Triumphalis Tarraco. Walter de Gruyter. Berlín / Nueva York.

Cosi, C. M. (1982). Aspetti mistici e misterici del culto di Attis. En: Bianchi, U. y Vermaseren, M. J. (eds.). La soteriologia dei culti orientali nell'impero romano. Atti del Colloquio Internazionale (Roma 1979). Leiden: 485-502.

De Visscher, F. (1963). Le Droit des Tombeaux romaines. Giuffre Ed. Milán.

DupRÉ, X. (1992). Mariangelo Accursio. Un humanista italià a la Catalunya de principis del segle XVI. En: Miscel-lània Arqueològica a Josep M. Recasens. Port de Tarragona. Tarragona: 45-56.

Duran, E. (1984). Lluís Ponç d'Icart i el Llibre de les grandeses de Tarragona. Barcelona.

Fabre, G., Mayer, M., RodÀ de Llanza, I. (1984). Inscriptions Romaines de Catalogne I. Barcelone (sauf Barcino). De Boccard. París.

Gamer, G. (1981). La "Torre de los Escipiones" y otros monumentos funerarios sucesores del Mausoleo de Halicarnaso. Boletín del Seminario de Estudios de Arte y Arqueología, 47: 71-94.

Gómez Pallarés, J. (2002). Poesia epigràfica llatina als Països Catalans. Edició i comentari. Barcelona.

Gonzalez, G., Carbonell, J. (eds.) (2012). Epigrafía hispánica falsa del primer Renacimiento español. Una contribución a la historia ficticia de la Península Ibérica. UAB. Bellaterra.

Gris, F., Ruiz de Arbulo, J. (2015). Torre de los Escipiones: de la interpretación a la divulgación del patrimonio. Virtual Archaeology Review, 12: 38-50.

Gros, P. (2002). L'Architecture romaine: du début du IIIe. siècle av. J.- C. à la fin du Haut-Empire 2. Maisons, palais, villas et tombeaux. Ed. Picard. París.

Gutiérrez Garcia-Moreno, A. (2009). Roman Quarries in the Northeast of Hispania (Modern Catalonia). Institut Català d'Arqueologia Clàssica. Tarragona.

Hauschild, T., Mariner Bigorra, S., Niemeyer, H. G. (1966). Torre de los Escipiones. Ein rómischer Grabturm bei Tarragona. Madrider Mitteilungen, 7: 162-188.

Hesberg von, H. (1994). Monumenta. I sepolcri romani e la loro architettura. Milán.

Hesberg von, H., Zanker, P. (1987). Romische Gräberstrassen. Selbstdarstellung, status, standar. München.

IRAT = GorostidI, D. (2010). Ager Tarraconensis 3. Les inscripcions romanes. IEC / ICAC. Tarragona. 
IRC = FABRe, G., MAYER, M., Rodì DE Llanza, I. (1984). Inscriptions Romaines de Catalogne I. Barcelone (sauf Barcino). De Boccard. París.

IR Mataró: Fabre, G., MaYer, M., RodÀ de Llanza, I. (1983). Inscripcions romanes de Mataró i la seva àrea (Epigrafia romana del Maresme). Mataró.

Kagan, R. (ed.) (1986). Ciudades del Siglo de Oro. Las vistas españolas de Anton van den Wyngaerde. El Viso. Madrid.

Kockel, V. (1983). Die Grabbauten vor den Herculaner Tor in Pompeji. Mayence.

Koppel, E. (1993). Atis en el context funerari romà. En: La Torre dels Escipions. Monuments a l'abast. Museu Nacional Arqueològic de Tarragona. Tarragona: 10-16.

LABORDE, A. de. (1806). Voyage pittoresque et historique de l'Espagne par Alexandre de Laborde, et une société de gens de lettres et d'artistes de Madrid. París.

LamuÁ, M. (2009). The Reliefs of the Roman Arch at Carpentras. En: Les ateliers de sculpture régionaux: techniques, styles et iconographie. Actes du Xe Colloque International sur l'Art provincial romain (Arles et Aix-en-Provence, 2007). Arles: 49-57.

Laplana, J. de C., Tarrats Bou, F., Sada, P. (2007). L'Antiguitat clàssica a través dels gravats: els Piranesi de Montserrat. Museu Nacional Arqueològic de Tarragona. Tarragona.

Lazzarini, S. (1991). Sepulcra familiaria. Uno studio epigrafico-giuridico. Pàdua.

LAZZARINI, S. (1997). Tutela legale del sepolcro familiare romano. En: Mirabella, M. (dir.). Monumenti sepolcrali romani in Aquileia e nella Cisalpina (Aquileia 1995). Trieste: 67-82.

Le Roux, P. (1982). L'armée romaine et l'organisation des provinces ibériques, d'Auguste à l'invasion de 409. París.

Liverani, P. (2008). Il Phrygianum vaticano. En: Palma Venetucci, B. (ed.). Culti orientali tra scavo e collezionismo. Artemide. Roma: 41-48.

Mar, R., Ruiz de Arbulo, J. (2011). Tarragona romana. República i Alt Imperi (anys 218 aC-265 dC). En: Història de Tarragona. 1. Tàrraco Clàssica i Prehistòrica. Pagès Editors. Lleida: 205-537.

Mar, R., Ruiz de Arbulo, J., Vivó, D., Beltran-CabALlero, J. A., Gris, F. (2015). Tarraco. Arquitectura y urbanismo de una capital provincial romana. Vol. 2: La ciudad imperial. URV/ICAC. Tarragona.

Massó, J., SADA, P. (1993). Historia de la investigación. En: La Torre dels Escipions. Monuments a l'abast. Museu Nacional Arqueològic de Tarragona. Tarragona: 26-35.

Mayer, M., Miró, M., Perea, R. (1993). La inscripción de la Torre dels Escipions. En: La Torre dels Escipions.
Monuments a l'abast. Museu Nacional Arqueològic de Tarragona. Tarragona: 16-21.

OJEDA, J. M. (1993). El servicio administrativo imperial ecuestre en la Hispania romana durante el alto Imperio. I. Prosopografía. Sevilla.

Pensabene, P. (2010). Culto di Cibele e Attis tra Palatino e Vaticano. En: International Congress of Classical Archaeology (Roma 2008). Bolletino di Archeologia on line, 23: 1-23.

Pons D'ICART, L. (1572/1573). Libro de las grandezas y cosas memorables de la metropolitana, insigne $y$ famosa ciudad de Tarragona. Lleida. Reed. Lleida 1883 y Tarragona 1981.

Ramallo, S., Ruiz Valderas, E. (1994). Un edículo republicano dedicado a Atargatis en Carthago Nova. Archivo Español de Arqueología, 67: 79-102.

Remolà Vallverdú, J. A. (2007). La imatge de Tàrraco recuperada. En: L'Antiguitat clàssica a través dels gravats: els Piranesi de Montserrat. Tarragona: 46-65.

RIT = ALFÖLDY, G. (1975). Die römischen Inschriften von Tarraco. Berlín.

Rodríguez González, J. (2003). Historia de las legiones romanas. 2 vols. Madrid.

Rovira Soriano, J., Dasca Roigé, A. (1993). La Torre dels Escipions. Museu Nacional Arqueològic de Tarragona. Tarragona.

Ruiz de Arbulo, J. (2008). Cuestiones económicas y sociales en torno a los santuarios de Isis y Serapis. La ofrenda de Numas en Emporion y el Serapeo de Ostia. En: Entre Dios y los hombres. El sacerdocio en la Antigüedad (Sevilla, 2004). SPAL Monografías, 7. Sevilla: 197-229.

Ruiz de Arbulo, J., Vivó, D. (2008). Serapis, Isis y los dioses acompañantes en Emporion. Una nueva interpretación del supuesto Asklepieion emporitano. Revista d'Arqueologia de Ponent, 18: 71-135.

SAdA, P., Remolà, J. A. (coord.) (2003). El Renaixement de Tarraco. Lluís Pons d'Icart i Anton van der Wyngaerde. Catálogo de la Exposición (Tarragona 2003). Museu Nacional Arqueològic de Tarragona. Tarragona.

SHÄFER, N. (2000). Die Einbeziehung der Provinzialen in den Reichsdienst in augusteischer Zeit. Franz Steiner Verlag. Stuttgart.

TARrats, F. (ed.) (2004). El renaixement de Tàrraco 1563. Lluís Pons d'Icart i Anton Van den Wyngaerde. Catàleg de l'Exposició. MNAT. Tarragona.

TurCan, R. (1989). Les cultes orientaux dans le monde romain. París.

Uroz, H. (2005). Sobre la temprana aparición de los cultos de Isis, Serapis y Caelestis en Hispania. Zephyrus, 23-24: 165-180. 
Ferran Gris, Joaquín Ruiz de Arbulo, El sepulcro turriforme conocido como la Torre de los Escipiones (Tárraco, Hispania citerior)

Valls, O., Massot, J. (1974). Alexandre de Laborde. Viatge pintoresc $i$ històric. El Principat. Abadia de Monsterrat. Barcelona.

Vermaseren, M. J. (1976). The Legend of Atis in Greek and Roman Art. Epro, 9. Leiden.

Vermaseren, M. J. (1977). Cybele and Atis. The Mythe and the Cult. Londres.

Vermaseren, M. J., De Boer, M. B. (1986) s.v. Atis en: Lexicon Iconographicum Mytologiae Classicae (LIMC), vol. 3.

Verzar-Bass, M. (1998). A proposito dei mausolei negli horti e nelle villae. En: Cima, M., La Rocca, E. (eds.). Horti Romani (Roma 1995). BCACR, suppl. 6. Roma: 401-424.
VIvó, D. (1998). El programa iconogràfic de l'Attideion del campo della Magna Mater en Ostia, Tesis doctoral leída en la Universitat de Girona. <http://hdl.handle. net/10803/7859>.

Vivó, D., Lamuá, M., Mar, R., Ruiz de Arbulo, J. (2011). La fachada oriental de la basílica forense de Tarraco. El monumento de los cautivos y el chalcidicum de culto imperial. En: XI Coloquio Internacional de Arte Romano Provincial (Mérida, mayo del 2009), vol. 2. Museo Nacional de Arte Romano de Mérida / ICAC. Roma: 863-872.

Zanker, P. (2002). Un'arte per l'Impero. Funzione e intenzione delle immagini nel mondo romano. Electa. Milán: 79-91. 